Cahiers $d u$ MONDE RUSSE

\section{Cahiers du monde russe}

Russie - Empire russe - Union soviétique et États indépendants

$44 / 1 \mid 2003$

Varia

\title{
Karl Radek i Bjuro meždunarodnoj informacii CK VKP(b), 1932-1934 gg.
}

\section{Oleg KEN}

\section{OpenEdition \\ Journals}

Édition électronique

URL : https://journals.openedition.org/monderusse/8603

DOI : 10.4000/monderusse.8603

ISSN : $1777-5388$

\section{Éditeur}

Éditions de l'EHESS

\section{Édition imprimée}

Date de publication : 1 janvier 2003

Pagination : 135-178

ISBN : 2-7132-1812-8

ISSN : $1252-6576$

Référence électronique

Oleg KEN, « Karl Radek i Bjuro meždunarodnoj informacii CK VKP(b), 1932-1934 gg. », Cahiers du monde russe [En ligne], 44/1 | 2003, mis en ligne le 01 janvier 2007, consulté le 02 septembre 2022. URL : http://journals.openedition.org/monderusse/8603 ; DOI : https://doi.org/10.4000/monderusse. 8603 


\section{CAIR N}

chercher : repérer : avancer

Cet article est disponible en ligne à l'adresse :

http://www.cairn.info/article.php?ID REVUE=CMR\&ID NUMPUBLIE=CMR 441\&ID ARTICLE=CMR 4410135

Karl Radek i Bjuro mezdunarodnoj informacii CK VKP(b), 1932-1934

gg

par Oleg KEN

| Editions de l'EHESS | Cahiers du monde russe

2003/1 - Vol 44

ISSN 1252-6576 | ISBN 2713218128 | pages 135 à 178

Pour citer cet article :

- KEN O., Karl Radek i Bjuro mezdunarodnoj informacii CK VKP(b), 1932-1934 gg, Cahiers du monde russe 2003/1, Vol 44, p. 135-178.

Distribution électronique Cairn pour les Editions de l'EHESS.

(C) Editions de l'EHESS. Tous droits réservés pour tous pays.

La reproduction ou représentation de cet article, notamment par photocopie, n'est autorisée que dans les limites des conditions générales d'utilisation du site ou, le cas échéant, des conditions générales de la licence souscrite par votre établissement. Toute autre reproduction ou représentation, en tout ou partie, sous quelque forme et de quelque manière que ce soit, est interdite sauf accord préalable et écrit de l'éditeur, en dehors des cas prévus par la législation en vigueur en France. Il est précisé que son stockage dans une base de données est également interdit. 


\section{OLEG KEN}

\section{КАРЛ РАДЕК \\ И БЮРО МЕЖДУНАРОДНОЙ ИНФОРМАЦИИ ЦК ВКП(Б), 1932-1934 ГГ*}

В предлагаемой работе предпринята попытка выяснить обстоятельства возникновения неформального института личного уполномоченного Сталина по международным делам (института, которому была суждено очень недолгое существование), исследовать формы его легитимации и эволюцию взаимоотношений с регулярными внешнеполитическими органами партии и правительства. Властная иерархия была пронизана горизонтальным соперничеством, персональными униями и клиентелизмом, и интересующие нас взаимоотношения органов власти и учреждений требуют пристального внимания к личности и образу действий сталинского агента - Карла Радека, одновременно «старого романтика» (J. Kowalewski) либо «последнего интернационалиста» (K. Lerner) и «engine of mischief» (J. Tuck), «often indulged in intrigue for its own sake» (J. Haslam) - личности яркой и неуловимой, поистине идеального «двойного агента» изменчивой, многовариантной реальности 30-х гг. На последней встрече с членами Политбюро в январе 1937 г. арестованный Радек определил свою роль, прибегнув к бюрократическому жаргону, нарочито невнятно: «внешник» ${ }^{1}$. Что скрывалось за этим тусклым выражением?

Ответить на этот вопрос невозможно без краткого обращения к основным проблемам советской внешней политики первой половины $30-$ х гг., в которой особое место заняла Польша, направляемая загадочным Пилсудским: станет ли она - главный из «ближайших вероятных противников» 20-х гг. - барьером, отделяющим СССР от агрессии Германии? плац-

\footnotetext{
* Благодарю А. Рупасова и Н. Елисеева за помощь в подготовке этой статьи, а также рецензентов, чьи замечания были любезно переданы мне редакцией. Основные материалы были собраны при работе над исследовательским проектом, поддержанным John D. and Katherine T. MacArthurs Foundation (1998-1999 гг.).

1. «'Все, что говорит Радек, - это абсолютно злостная клевета...', Очная ставка К. Радека и Н. Бухарина в ЦК ВКП(б) 13 января 1937 г.», Источник: документьь русской истории, № 1, 2001, с. 70 .
} 
дармом для нападения на СССР? (или, может быть, плацдармом для возобновления прерванного в 1920 г. большевистского похода на Запад?) $)^{2}$.

Соединение в рамках одной работы слишком большого числа вопросов обычно вызывает законную настороженность. Математики, впрочем, хорошо знают, что уравнения с несколькими неизвестными, бывают необходимы для описании сложных явлений, а объединение таких уравнений в систему позволяет найти значение каждой переменной. Подобным образом в своем изложении автор пытался объединить загадочные исторические сюжеты и соответствующие группы источников. Разумеется, этот метод способен лишь частично компенсировать крайнюю неполноту и разрозненность доступной ныне документации о деятельности Бюро международной информации. До подведения итогов еще далеко.

\section{Предпосылки создания БМИ (осень 1931 - весна 1932 г.)}

Развертывание «наступления социализма по всему фронту» в 1929-1932 гг. обострило отношения СССР с окружающим миром и явилась катализатором кризиса советской внешней политики. Прагматическое миролюбие и идеологические антиверсальские установки обусловливали на протяжении 20-х гг. нескрываемую «общность интересов Советского Союза с пострадавшими от войны государствами», в первую очередь, с Германией ${ }^{3}$. Международный баланс сил, на котором основывалась внешняя политика СССР, быстро размывался. Возрождение германской мощи и постепенное освобождение ее от скреп, наложенных в Версале, вело к системному кризису Рапалло. В начале 1930 г., одновременно с решением о досрочной эвакуации Рейнской зоны, дезинтеграция политического сотрудничества СССР и Германии приобрела острые формы. Вслед за этим, в марте 1930 г., Кремль охватила «военная тревога» - опасения, что крестьянские волнения в приграничных округах Украины и Белоруссии могут подтолкнуть польское правительство к вмешательству. К концу весны 1930 г. Советам удалось стабилизировать отношения с Германией. Представление о стремлении Пилсудского повторить 1920 год оказалось по меньшей мере преувеличенным и подверглось пересмотру. Качели советской политики двинулись в другую сторону — осенью 1930 г. Москва настойчиво провоцировала кризис в отношениях с Францией, обвиняя ее политическое и военное руководство в непосредственной подготовке антисоветской интервенции. К апрелю 1931 г., сыграв отведенную ей внутриполитическую роль, антифранцузская кампания сменилась попытками восстановить торгово-экономическое сотрудничество с Францией и нормализовать двусторонние политические отношения. Достижение одновременной договоренности с Пари-

2. См. раздел «Буржуазная Польша - плацдарм или барьер» в сборнике статей К. Радека Подготовка борьбы за новый передел мира, М., 1934.

3. «Интервью Наркома иностранных дел СССР М. М. Литвинова, 23.7.1930», Документы внешней политики СССР, т. ХІІІ: 1 января - 31 декабря 1930 г., М., 1968, c. 425. 
жем относительно пакта о ненападении и неучастии во враждебных комбинациях (текст которого был тайно парафирован в августе 1931 г.) и продление аналогичного договора СССР с Германией (июнь 1931 г.) оживили иллюзорные надежды на участие России в концерте «великих держав» или даже создании «континентального блока». Отказ французской дипломатии от закрепления политических договоренностей с СССР без участия в них Польши разрушил эту умозрительную идиллию.

Впервые после Генуэзской конференции Москва оказалась перед фундаментальным выбором. Вступление в переговоры с Польшей о заключении договора ненападения влекло за собой фактическое признание со стороны СССР ее права на существование в установленных после мировой войны границах и тем самым отрицание ревизионистских притязаний Германии. Если сближение с Францией допускало сохранение сотрудничества СССР с Германией, то установление партнерских отношений с Польшей означало уничтожение стратегической основы такого сотрудничества. Осознавая многообразные последствия, которые должно было повлечь за собой вступление СССР в переговоры с Польшей о пакте ненападения, руководство НКИД считало необходимым до последней возможности уклоняться от пересмотра основ советской политики. О «крепкий утес наших взаимоотношений с Германией» разбивались «попытки создания единого капиталистического фронта против СССР», напоминал Политбюро нарком по иностранным делам Максим Литвинов. «Когда мы найдем это выгодным для себя, мы пойдем и на пакт с Польшей, вопреки Рапалло», но это время, настаивало руководство НКИД, еще не пришло и для достижения компромисса с Францией следует отыскать иные пути ${ }^{4}$.

Позиция Сталина оказалась почти диаметрально противоположной. Возможно, он недооценивал многообразные международные последствия будущего советско-польского договора, но хорошо осознавал, что проблема нормализации отношений СССР с Польшей - это «вопрос о мире», в котором отчаянно нуждалась страна, проходившая через период тотальной ломки прежних устоев. В директивном письме Кагановичу, председательствовавшему в то время в Политбюро, Генеральный секретарь ЦК ВКП(б) назвал заключение пакта с Польшей делом «очень важным, почти решающим (на ближайшие два-три года)»5. Находясь вдали от столицы, Сталин с редкой проницательностью определил мотивы польского правительства, предложившего Москве вернуться к прерванным в 1927 г. переговорам о пакте ненападения и высмеял презрительное отношение НКИД к польской инициативе 6 . Едва ли не беспрецедентная конфронтация между сталинским Политбюро и руководством дипломатического ведомства в конце августа - сентябре 1931 г. завершилась полным поражением послед-

4. Записка Наркома иностранных дел М. М. Литвинова Секретарю ЦК ВКП(б) Л. М. Кагановичу (копии членам Политбюро), 15.9.1931, Архив внешней политики РФ [далее - АВП], /010/4/21/63/242, 253.

5. Письмо И. В. Сталина Л. М. Кагановичу, 30.8.1931, Российский государственный архив социально-политической истории [далее - РГАСПИ], /81/3/99/12-13.

6. Письмо И. В. Сталина Л. М. Кагановичу, 7.9.1931, РГАСПИ, 81/3/99/21-22. 
него. НКИД было предписано совершить решительный поворот к переговорам с Польшей и другими западными соседями СССР о заключении двусторонних пактов ненападения ${ }^{7}$ Месячный кризис в отношениях с непослушным дипломатическим ведомством преподал высшему политическому руководству несколько важных уроков. Во-первых, все руководители и ведущие сотрудники НКИД заняли по существу единую позицию, которую они защищали на протяжении четырех недель и от которой отказались только после решения Политбюро «отвергнуть установку т. Литвинова». Тем самым обнаружился серьезный сбой в механизме поддержания конкуренции между противоборствующими группировками в НКИД - механизме, который отлаживался и поддерживался в рабочем состоянии на протяжении всего послеленинского периода. Однако в конфликтном вопросе о пакте с Польшей все четыре члена Коллегии НКИД заняли консолидированную позицию, от которой под нажимом Сталина отступил (и то лишь отчасти) только «чичеринец» Карахан старый недруг наркома Литвинова. Положение усугублялось тем, что центральный партийный annapam не располагал институциональными структурами, которые были бы сопричастны деятельности государственного ведомства по иностранным делам или контролировали его текущую деятельность.

Во-вторых, дискуссии сентября 1931 г. выявили крайнюю недостаточность аутентичной политической информации, необходимой для принятия в Москве ответственных решений. «По получении Вашего письма, докладывал Каганович Сталину, - [мы, т.е. члены Политбюро. - Авт.] затребовали новые данные от НКИД. Никаких серьезных материалов у них нет» ${ }^{8}$. Со своей стороны, десятью днями позже нарком Литвинов признал ненадежность нового доклада о ситуации в Польше, который его ведомство направило в Политбюро: составителям политического раздела доклада пришлось «оперировать в значительной степени догадками, предположениями, непроверенными дипломатическими россказнями. Более серьезно обоснованы экономическая и финансовая части записки». Для принятия решений советским вождям, однако, была нужны не марксистская характеристика сельскохозяйственной конъюнктуры в соседней стране, а трезвый анализ расстановки сил в ее правящих сферах, политического мышления и

7. В этом описании и последующем анализе использованы выводы предшествующих работ: Oleg Ken, Collective security or isolation? Soviet foreign policy and Poland, 19301935, St. Petersburg, 1996; О. Н. Кен, А. И. Рупасов, Политбюро ЦК ВКП(б) и отношения СССР с западньми соседними государствами (конеи, 1920-1930-х г2.): Проблемы. Документы. Опьт комментария, часть 1: 1928-1934, С.-Петербург, 2000 (разделы I, IV); Oleg Ken, «Alarm wojenny» wiosną 1930 roku a stosunki sowieckopolskie, Studia z Dziejów Rosji i Europy Środkowo-Wschodniej, t. XXXV, 2000, s. 41-73.

Применительно к общим проблемам советской политики 30-х гг. наиболее авторитетными остаются работы Дж. Хаслама (в особенности: Jonathan Haslam, The Soviet Union and the struggle for collective security in Europe, 1933-1939, L., 1984). Лучший анализ советско-польских отношений в межвоенную эпоху принадлежит В. Матерскому (Wojciech Materski, Tarcza Europy: Stosunki polsko-sowieckie, 1918-1939, Warszawa, 1994).

8. Письмо Л. М. Кагановича И. В. Сталину, 5.9.1931, РГАСПИ, /81/3/101/15. 
воззрений тех, кто направляет ее внешнюю политику (например, фактического диктатора Польши маршала Пилсудского). В период конфликта 1931 г. Литвинов объяснял недостаток достоверной информации исключительно дефектами в деятельности полпредства в Варшаве (оно «весьма слабо связано с общественными кругами Польши, серьезных источников информации не имеет»9). Нарком предпочел не вспоминать о попытке своего предшественника создать в НКИД аналитический центр - Отдел информации и печати, в котором «были референты по разным странам, за политикой и внутренним состоянием разных стран великолепно следили» 10 . К началу 30-х гг. функции этого Отдела были сведены к работе с прессой, а его прежний руководитель (Федор Ротштейн) отправлен в отставку. Предложение восполнить возникшую брешь путем создания при Наркоминделе научно-экспертного «института внешней политики» 11 успеха не имело. Немногим, по всей вероятности, могли помочь политическому анализу советские спецслужбы - IV (Информационно-Статистическое, позднее - Разведывательное) Управление Штаба РККА и Иностранный отдел ОГПУ. Донесения военной разведки, насколько можно судить по отдельным материалам середины 30-х гг., отличали специфичность основных объектов изучения (армия, технология, экономика) и фрагментарность; общие доклады и заключения Разведывательного управления фактически отождествляли военно-экономические возможности (capabilities) соседних стран и великих держав с политическим намерением (intentions) этих государств использовать их для агрессии против Советского Союза. Материалы советской военной разведки конца 20-х - начала 30-х гг. убедительно подтверждают мысль С. Хантингтона: «The military man is professionaly capable of estimating the fighting strength of another state. But judging its policies is a matter of politics outside his competence.» ${ }^{12}$

На протяжении болььшей части 20 -х гг. Москва располагала возможностью использовать для государственных нужд информационноаналитические структуры Коммунистического Интернационала. Главной из них являлся созданный в 1921 г. «Институт в Берлине» («Информационное бюро», «Бюро Варги»), задачи которого состояли в изучении не столько социально-экономических, сколько политических проблем современного Запада ${ }^{13}$. Этот орган работал под прикрытием советского дипломатического представительства в Берлине, и под влиянием паники, охватившей советское руководство после полицейских инцидентов в Шанхае и Лондоне

9. Записка Наркома иностранных дел М. М. Литвинова Секретарю ЦК ВКП(б) Л. М. Кагановичу (копии членам Политбюро), 15.9.1931, АВП, /010/4/21/63/240.

10. Записка Наркома иностранных дел Г. В. Чичерина [В. В. Куйбышеву], [начала июля 1930 г.], Источник, № 6, 1995, с. 100.

11. Письмо полпреда в Финляндии И. М. Майского Заместителю наркома по иностранным делам Л. М. Карахану, 31.8.1930, АВП, /010/1/74/79/9-11.

12. Samuel P. Huntington, «The military mind», in Malham M. Wakin, ed., Morality and the military profession, Boulder, CO, 1979, p. 33.

13. Г. М. Адибеков и др., Организационная структура Коминтерна: 1919-1943, М., 1997, c. $55-56$ 
весной 1927 г., в середине этого года был ликвидирован ${ }^{14}$. Информационный отдел Исполкома Коминтерна, который с 1920 г. готовил аналитические записки не только о деятельности коммунистических партий, но и о политическом положении в отдельных странах (одним из его видных сотрудников был Рихард Зорге), летом 1929 г. также был расформирован ${ }^{15}$. Информационные материалы территориальных отделов (Ländersekretariaten) Коминтерна годились скорее для пропаганды и проведения партийных чисток, чем для лучшего понимания общеполитических процессов.

К сказанному остается добавить, что к началу 30-х гг. ни один из государственных институтов, не говоря уже о структурах Коминтерна, не обладал правом регулярного получения международно-политической информации от других органов и, с другой стороны, в силу своих специфических задач и характерного для тех лет кадрового голода, не был в состоянии обеспечить общую независимую экспертизу по важнейшим для Москвы проблемам внешней и внутренней политики иностранных государств.

В-третьих, процесс определения курса Москвы по отношению к «польско-французской» проблеме на рубеже лета-осени 1931 г. обнаружил слабость высшего звена принятия внешнеполитических решений. В отсутствие Сталина руководимое Кагановичем Политбюро доверчиво восприняло заверения НКИД о необходимости разоблачить новые интриги Польши и ничего не предприняло, чтобы помешать Литвинову и ТАСС в конце августа публично (и настойчиво) заявлять о бесперспективности переговоров с нею. Если бы не энергичное вмешательство Сталина, Москва не только вновь загнала бы в тупик свои отношения с Польшей и другими соседними странами, но и могла утратить достигнутое с трудом взаимопонимание с Францией. Генеральному секретарю пришлось убедиться, что его партийные соратники неспособны к самостоятельному анализу новых международных факторов и легко поддаются общему поветрию. Вместе с тем, они проявили (надо полагать, не впервые) полную готовность слушаться палочки своего дирижера: проблемы международной политики находились на периферии их забот. В отличие от административно-экономических вопросов, рассмотрение которых членами Политбюро - руководителями заинтересованных ведомств, было необходимо для достижения компромиссов и общего согласия, международно-политические решения не имели прямого отношения к основной - ведомственной - компетенции высших советских деятелей, и изъятие этого комплекса (или некоторой его части) из сферы работы Политбюро как будто не угрожало основам сложившегося «олигархического» порядка. Уже в двадцатые годы обыкновение наркома по иностранным делам Чичерина «приносить на заседание Политбюро кипы литературы по теме своего сообщения вызывало чуть ли не смех у циничных прагматиков, перед которыми он

14. Протокол заседания Политбюро ЦК ВКП(б) № 21 от 25.8.1927, РГАСПИ, /17/162/5/89.

15. Г. М. Адибеков и др., указ. соч., с. 117. 
выступал» 16 , и они не имели ничего против того, чтобы избавиться от выслушивания прений о нюансах международной дипломатии. Возможно, единственным исключением был неутомимый Председатель Совнаркома Молотов, не без гордости вспоминавший о своей тогдашней причастности к иностранной политике: «В Политбюро все идет. Никакого отдела не было. И надо же знать международные дела, читать секретные шифровки, никто не читал, кроме меня» 17 .

Мы вряд ли ошибемся в утверждении, что эти вопросы были среди тех, что сильно занимали ум Сталина ранней осенью 1931 г. Годом ранее, отдых на Северном Кавказе позволил ему обдумать (и в письмах Молотову подготовить) перестройку деятельности Совнаркома СССР, которая воплотилась в решениях декабря 1930 г. Без большого риска мы вправе также предположить, что прогуливаясь на правительственной даче в сентябре 1931 г. Сталин наметил реформу системы принятия внешнеполитических решений, которая последовательно выразилась в формировании новых комиссий Политбюро по международным делам, создании нового органа по информационному обеспечению, и, наконец, появлению неформального института - специального уполномоченного Сталина по внешним делам.

В конце ноября 1931 г., после того как новые переговоры с Францией подтвердили неизбежность вступления СССР в деловые переговоры с Польшей и другими западными соседними государствами об взаимных обязательствах ненападения, членам Политбюро были направлена для подписания (заочного голосования) туманная резолюция: «Поручить комиссии в составе тт. Сталина, Молотова и Кагановича наметить ряд необходимых мероприятий, вытекающих из нынешней международной обстановки». Спустя месяц в состав этой комиссии (получившей название Комиссии по международным делам) был введен видный член Политбюро, нарком тяжелой промышленности Орджоникидзе. Анализ ноябрьского решения в контексте протоколов Политбюро начала 30-х гг. показывает, что к деятельности Комиссии по международным делам была отнесена проблематика политических взаимоотношений со странами Балтии, Румынией, а также (по меньшей мере, косвенно) с Францией, Германией, Польшей и Турцией. Двумя днями позже, 26 ноября 1931 г., нарком Литвинов предложил Сталину «образовать небольшую комиссию Политбюро для дальнейшего руководства переговорами» с Польшей. В тот же день через Политбюро было проведено решение о создании Комиссии по советско-польским делам, в которую вошли Сталин, Молотов и от наркомата иностранных дел - Литвинов и Стомоняков. В отличие от множества создававшихся ad hoc комиссий Политбюро, эти органы не имели четко ограниченных задач и срока работы. По существу, во многих вопросах внешней политики они подменили собой Политбюро, которое, в частности, на протяжение последующего года было отстранено от рас-

16. «В Наркоминделе, 1922-1939: Интервью с Е. А. Гнединым», Память: исторический сборник, вып. 5, М., 1981; Париж, 1982, с. 387.

17. Ф. Чуев, Молотов: полудержавный властелин, М., 1999, с. 246. 
смотрения политических взаимоотношений с Польшей и Румынией (с которыми велись тогда интенсивные переговоры). Исключением стали лишь летние месяцы 1932 г., когда Сталин находился в отпуске и комиссии с его участием собираться не могли ${ }^{18}$. В конце 1931 г. была образована Комиссия Политбюро по Маньчжурскому вопросу. Ранее созданная Монгольская комиссия в марте 1932 г. была преобразована в постоянную комиссию Политбюро по разрешению всех вопросов, касающихся Монголии ${ }^{19}$.

Мы почти ничего не знаем о внутренней деятельности этих комиссий: документы на этот счет (если они сохранились) скрыты за стенами Архива Президента РФ. Тем не менее есть основания полагать, что экспертным рабочим аппаратом комиссии Политбюро не располагали и в своих решениях исходили из предложений прежних регулярных органов, государственных и партийных.

Начатая Сталиным реформа внешнеполитических органов была продолжена принятым по его инициативе решением Политбюро. 1 апреля 1932 г. оно постановило: «Организовать при ЦК информационное бюро по международным вопросам во главе с т. Радеком.» 20

\section{Возвышение Радека}

С самого начала и на протяжении последующих четырех с половиной лет новый орган, вскоре названный Бюро международной информации (БМИ) ЦК ВКП(б) прочно ассоциировался с именем Радека. Член Социал-Демократии Королевства Польского и Литвы, Социал-Демократической партии Германии, циммервальдист, член Исполкома Коминтерна и докладчик на его конгрессах, ректор Коммунистического университета имени СунЯтсена, в своей обширной автобиографии он даже не упомянул о вступлении в партию большевиков и избрании в ее ЦК $(1919 \text { г. })^{21}$. Публицист с

18. О. Н. Кен, А. И. Рупасов, указ. соч., с. 562-564.

19. См.: Kyosuke Terayama, «Soviet policies towards Mongolia after the Manchurian incident, 1931-1934», in Tadashi Yoshida and Hiroki Oka, eds., Facets of transformation of the Northeast Asian countries, Tohoku, 1998, p. 40-42; В. Шепелев. «"Монгольский вопрос" на заседаниях Политбюро ЦК ВКП(б)», РЦХИДНИ, Научноинформационный бюллетень, № 8, 1996, с. 63-64.

20. Протокол № 94 заседания Политбюро ЦК ВКП(б) от 1.4.1932, РГАСПИ, /17/3/878/5. Перед вынесением этого решения (27 марта) Сталин и Радек полтора часа беседовали наедине (А. В. Коротков и др. (публ.). «Посетители кремлевского кабинета И. В. Сталина», [далее - Посетители], Исторический архив, № 2, 1995, c. 138).

21. Переиздание автобиографии К. Радека (1925 г.): Деятели CСCP u революционного движения России: Энциклопедический словарь Гранат, М., 1989, c. 593-609. Выход в свет романа Stefan'a Heym'a Radek вызвал обсуждение различных эпизодов жизни героя немецкой прессой (в частности: Freimut Duve, «Gespenst des Jahrhunderts», Der Spiegel, № 17, 1995, c. 220-223). Обзор откликов на роман Неут’а см.: Meg Tait, «Stefan Heym's Radek: The conscience of a revolutionary», German Life and Letters, vol. 51, Oct. 1998, p. 496-508. Едва ли не лучшая зарисовка облика Радека принадлежит В. Сержу (Victor Serge, Memoirs of a revolutionary, 1901-1941, Oxford, 1975, p. 136-137). 
двумя десятками псевдонимов, Радек до конца жизни испытывал затруднения с русским языком. К социал-демократии тарновского еврея-гимназиста привела мечта о независимой Польше; и в пятьдесят лет он не расставался с сочинениями польских романтиков ${ }^{22}$. Самостоятельность мышления, привычка к оппозиционности и былая близость к Розе Люксембург и Льву Троцкому, несдержанность и язвительность языка, казалось, подтверждали верность «говорящему» партийному псевдониму, который в юности взял себе Карл Собельсон - преданный читатель романов Стефана Жеромского ${ }^{23}$. Решение поручить ему ответственную политическую работу настолько диссонировало с утверждавшимися в начале 30-х гг. правилами отбора партийных кадров, что отдавало провокацией (характерны курьезные откровения ответственного редактора Известий, который заверял польских дипломатов, что в ходе проводимой партийной чистки «защитит Радека, который вовсе не является троцкистом» $\left.{ }^{24}\right)$. Тем не менее у этого сталинского назначения была своя логика.

Весной 1929 г. Радек, отбывавший с начала 1928 г. ссылку за принадлежность к «марксистско-ленинской оппозиции», вместе со Смилгой и Преображенским в письме руководству ВКП(б) заявил о своем отказе от троцкистской платформы и солидаризировался с генеральной линией партии. Спустя полгода он был восстановлен в партии и переведен из Сибири в Центральную Россию («в провинцию, исключив Московскую и Ленинградскую области и Украину» ${ }^{25}$ ). В начале 1930 г., в связи с предложением Горького наладить издание журнала За рубежом, в верхах возникла мысль о возвращении Радека к публицистической деятельности 26 . Генеральный секретарь и его «друзья» (по выражению Сталина) не согласились отдать этот журнал под руководство Радека; впрочем, в письме Горькому 17 января 1930 г. Сталин уже не ставил под сомнение «добрые намерения» и «добросовестность» Радека. Главное препятствие, по его словам, состояла в том, Радек и «его друзья» «не отказались полностью» от фракционной борьбы, между ними и ЦК «остались некоторые важные разногласия, которые будут толкать их на борьбу». Все же Сталин обещал

22. CM.: Notatka attaché wojskowego RP w Moskwie K. Zaborowskiego «Rozmowa z Radkiem dnia 14.3.1936 r.», Centralne Archiwum Wojskowe, Warszawa [далее - CAW], $/ 1775 / 89 / 1136 / 236$.

23. Радек - «радикальный»(?) — имя персонажа одной из книг С. Жеромского. Увы, называлась она «Сизифов труд».

24. Raport chargé d'affaires RP w Moskwie H. Sokolnickiego do Ministra Spraw Zagranicznych J. Becka, Moskwa, 21.12.1932, CAW, /1775/89/538/244.

25. Протокол заседания Политбюро ЦК ВКП(б) № 106 (особый № 104) от 5.11.1929, РГАСПИ, /17/162/3. Одновременно с принятием этого решения Политбюро подвергло критике ОГПУ за то, что оно «не сумело в свое время выявить и ликвидировать изменническую антисоветскую работу Блюмкина» и распорядилось расстрелять его (там же, /17/162/2). Цитируемый документ опровергает версию Троцкого о том, что посетившего его в Константинополе Блюмкина выдал на расправу ренегат Радек (Л. Троцкий, «Радек»; он же, Преступления Сталина, М., 1994, с. 156).

26. Вероятно, новое издание задумывалось взамен журнала НКИД Международная жизнь. Журнал НКИД в 1930 г. перестал выходить, но За рубежом стало издаваться в формате популярной газеты. 
привлечь Радека в качестве сотрудника нового журнала 27 . Вскоре Радек предложил Правде свои услуги в реферировании и критике зарубежной публицистики. 8-9 марта 1930 г. Политбюро опросом утвердило решение: «Предложить т. Ярославскому сообщить Радеку, что редакция Правды не возражает против помещения время от времени статей т. Радека, особенно статей о книге Денни [Америка завоевывает Британию. - Авт.]» ${ }^{28}$. Спустя месяц по предложению Сталина Политбюро постановило: «Разрешить т. Радеку переезд в Москву» ${ }^{29}$. Это решение было равносильно официальной реабилитации К. Радека: его вновь признали «товарищем».

Если поворот «влево» в советской внутренней политике создал благоприятный фон для возращения раскаявшегося «троцкиста» к официальной политической жизни, то причины заинтересованности Кремля в его услугах лежали, думается, в упомянутом выше резком ухудшении ситуации на западных рубежах СССР. Крестьянские волнения в западных округах Украины и опасения Кремля, что «польское правительство может пойти на вмешательство», достигли своей кульминации около 10 марта; как раз в эти дни Генеральный секретарь счел целесообразным попросить коллег по Политбюро высказаться относительно «книги Денни». Вероятно, уже тогда дискуссии в Москве о том, поддастся ли Пилсудский искушению воспользоваться временной слабостью восточного соседа и прибегнет к «превентивной войне», обнаружили недостаточную информированность советского руководства, подчеркнули отсутствие прямых каналов связи с польской верхушкой. Поведение Пилсудского и даже приоритеты советской политики в отношении Польши в ответственных ведомствах оценивали порой прямо противоположным образом ${ }^{30}$. Вероятно, кризис в отношениях с Германией и Польшей весной 1930 г. заставил Сталина ощутить потребность в людях, благодаря своему опыту, личным связям и аналитическим навыкам способным осмыслить и использовать те возможности, которые открывали для СССР перемены на линии Варшава-Берлин.

Со времени своего руководства Отделом Центральной Европы Наркоминдела и Отделом внешних сношений ЦИК РСФСР (1918 г.) Карл Радек с большим успехом выполнял такие задачи. Достаточно вспомнить, что его неофициальные переговоры в Берлине, которые он начал находясь в тюрьме Моабит (1919 г.), не только привели к недолговечному союзу большевиков с Энвер-пашой, но и подготовили сближение Германии с

27. «Письмо А. М. Горькому, 17.01.1930», И. Сталин, Собрание сочинений, т. 12, М., 1953 , с. 175 .

28. Протокол заседания Политбюро ЦК ВКП(б) № 120 от 15.3.1930, РГАСПИ, $/ 17 / 3 / 779 / 12$.

29. Протокол заседания Политбюро ЦК ВКП(б) № 123 от 15.4.1930, там же $1 / 7 / 3 / 782 / 9$

30. Осенью 1929-весной 1930 гг. Политбюро несколько раз обращалось к различным аспектам отношений с Польшей, по которым обнаруживалось резкое расхождение между Наркоминделом и харьковскими партийно-государственными учреждениями (см.: О. Н. Кен, А. И. Рупасов, указ. соч., с. 501-506). 
Советской Россией ${ }^{31}$. Известное высказывание Ленина, что «при всех своих многочисленных достоинствах» Радек «совершенно не годится в дипломаты», вызванное несанкционированным интервью Радека, в котором он сообщил о переговорах Раковского с представителями Франции в предверии Генуэзской конференции ${ }^{32}$, заслуживает доверия лишь отчасти. Первоначальный план Раковского был утопичен и сильно окрашен его личными («романскими») симпатиями: наподобие царского премьера С. Ю. Витте он мыслил категориями «большой коалиции», в рамках которой экономический союз России и Германии сопровождался бы заключением ими «соответствующих договоров» с Францией. Радек, напротив, делал ставку на разжигание франко-германского антагонизма, и как показала последующая история взаимоотношений Москвы и Берлина, сотрудничество между ними действительно оказалось возможным лишь на антифранцузской основе. Заявление Радека о контактах Советов с французами «заставило сильно насторожиться Германию» ${ }^{33}$ и по существу предвосхищало тактику советской делегации в Генуе, увенчавшуюся заключением Рапалльского договора. Неудивительно, что вслед за этим Ленин, Сталин, Троцкий и Чичерин без возражений приняли рекомендации Радека относительно поведения российской делегации на Лозаннской конференции 1922 г. ${ }^{34}$

После присоединения Радека к партийной оппозиции в РКП(б) и выступления против отказа Коминтерна от тактики единого фронта (конец 1923 - начало 1924 г.) его неофициальная дипломатическая деятельность (которой, странным образом, не помешали перемежавшиеся с нею нелегальные экспедиции для организации германской революции) сузилась до эпизодического зондирования германских и польских политических кругов и в 1925 г. фактически оборвалась. Один из немногих влиятельных московских политиков, последовательно возражавших против «похода на Вислу» в 1920 г. ${ }^{35}$, Радек в середине 20-х гг. (когда переговоры об заключении Локарнского договора и о вступлении Германии в Лигу Наций привели к сближению Берлина и западных столиц) принял активное участие в разыгрывании польской карты. Летом 1925 г. в беседе с лицом, близким к польской миссии в Берлине, Радек сообщил о попытках Auswärtiges Amt приступить к обсуждению с советскими представителями раздела Польши, выразил убеждение, что Россия ни в малейшей степени не заинтересована в

31. Высокую оценку деятельности Радека на этом поприще см. в последней работе сотрудника МИД России: С. А. Горлов, Совершенно секретно: Альянс Москва Берлин, 1920-1933 г2. (Военно-политические отношения СССР-Германия), М., 2001, c. 26-30.

32. См.: «Записка В. И. Ленина В. М. Молотову для всех членов Политбюро, 20.2.1922», В. И. Ленин, ПСС, т. 54, с. 176; В. А. Головко, М. Г. Станчев, Г. И. Чернявский, Между Москвой и Западом. Дипломатическая деятельность Х. Г. Раковского, Харьков, 1994, с. 106.

33. Там же, с. 107 (из письма Иоффе в Политбюро ЦК РКП(б)).

34. Там же, с. 134-135.

35. См.: Piotr Stefan Wandycz, Soviet-Polish relations, 1917-1921, Cambridge (MA), 1969, p. $216-217,249,254-255$ 
непосредственном соседстве с Германией, поскольку она может стать орудием капиталистического блока. Польские дипломаты имели все основания заключить, что тем самым Радек пытался вызвать интерес с заключению пакта о ненападении между Польшей и СССР ${ }^{36}$. В сентябре 1925 г., в связи с переговорами наркома иностранных дел в Варшаву о вступлении в переговоры о советско-польском пакте ненападения, Радек на страницах печати доказывал, что в условиях дрейфа Германии в сторону Запада СССР не может быть заинтересован в ослаблении Польши ${ }^{37}$. Эти установки Радека в начале 1930-х оказались в полном соответствии с обеспокоенностью Сталина относительно «общественного поветрия 'антиполонизма'» в московских кругах, под «давлением» которого возможность заключения договора о ненападении с Польшей может быть «сведена к пустышке» вопреки «интересам революции и социалистического строительства» ${ }^{38}$.

Разумеется, Карл Радек был не единственным талантливым публицистом-дипломатом, к услугам которого мог прибегнуть Кремль. Так, впечатляющий послужной список имел ровесник Радека и уроженец Польши Стефан Раевский (Нейман): советник полпредства в Берлине, представитель ТАСС в Париже и - неофициально: «tиуаи», в контактах с немцами и поляками осуществлявший «тактические маневры, предписанные сверху, имеющие свою цель и определенные задачи» ${ }^{39}$. В отличие от Радека, симпатизировавший троцкизму Раевский не упорствовал в ереси и оставался видным советским публицистом, возглавив (с 1928-1929 гг.) Иностранный отдел главного официоза - газеты Известия. В партийных кругах и ОГПУ к нему все же относились с недоверием, которое, возможно, не было вовсе беспочвенным. «Раевский вообще так ополячился, отмечал в 1932 г. польский военный атташе, — что теперь все время говорит о большевиках “они” в отличие от Радека, который говорит “мы” или “Сталин”. » ${ }^{40}$ Кроме того, Раевский никогда не пользовался ни таким влиянием в партийных, наркоминдельских и коминтерновских кругах, ни такой журналистской известностью как Карл Радек. С другой стороны, следуя

36. Raport posła RP w Berlinie A. Wysockiego do MSZ, Berlin, 20.7.1925, Archiwum Akt Nowych, Warszawa (далее - AAN) /Ambasada RP w Londynie/32/92. О фактической стороне см.: Zygmunt J. Gąsiorowski, «The Russian overture to Germany of December 1924», The Journal of Modern History, vol. XXX, No. 2, June 1958, p. 100-105.

37. См.: Josef Korbel, Poland between East and West. Soviet-German diplomacy toward Poland, Princeton (NJ), 1963, p. 173-174.

38. Письмо И. В. Сталина Л. М. Кагановичу, Сочи, 30.8.1931, РГАСПИ, /81/3/99/1213.

39. «Письмо посланника РП в Москве С. Кентшинского министру иностранных дел РП А. Залесскому, 20.7.1926», Документы и материаль по истории советскопольских отношений [далее - ДиМ], т. VI, 1926-1932, М., 1968, с. 28-29. Вероятно, именно Раевскому посвящен доклад польского посланника в Берлине «Rozmowa z p. R.» (Берлин, 5.10.1927) (AAN/Ambasada RP w Berlinie/264/39-41).

40. Rozmowa podpułkownika J. Kowalewskiego z redaktorem Izwiestij Gronskim w dniu 7 listopada 1932 roku na przyjęciu u Kalinina, Центр хранения историко-документальных коллекций [далее — ЦХИДК], М., /308/12/120/63. 
архетипам властвования ${ }^{41}$, Сталин, вероятно, предпочитал поднять из праха грешника, который испытал тяжесть его гнева и в случае возвышения, был бы всем обязан хозяину 42 .

Протоколы Политбюро и советская печать позволяют проследить быстрое возвышение Радека. В августе 1930 г. он был назначен членом редакционной коллегии Известия ЦИК СССР и введен в «комиссию Коминтерна по руководству V конгрессом Профинтерна» 43 . Спустя полгода Радек предложил (и Политбюро согласилось) развернуть пропагандистскую кампанию «в ответ на лживую кампанию буржуазной печати о принудительном труде в СССР» ${ }^{44}$. В начале 1932 г. особым решением Политбюро «О тов. Радеке» он был включен в состав делегации СССР на Конференции по разоружению ${ }^{45}$ и развернул в Женеве некую «работу» 46 . Весной 1932 г. звезда Радека поднялась высоко. Через месяц после назначения его главой нового Бюро международной информации ЦК ВКП(б) в протоколе Политбюро появилась неясная по существу, но крайне лестная для Радека запись - запись, о которой любой высокопоставленный аппаратчик мог только мечтать: «1. [Слушали:] Сообщение т. Сталина (тт. Сталин, Радек). [Постановили:] Поручить тов. Ворошилову и Радеку уладить это дело» ${ }^{4}$.

41. В российской традиции, «для функционеров, представлявших институт самодержца, характерна принадлежность к неродовитым дворянским родам и отсутствие тесных связей с собственным сословием, что обеспечивало их лояльность к самодержцу как к источнику благ, сохранение расположения которого было залогом их удачной карьеры» (П. Мустонен, Собственная его императорского величества канцелярия в механизме властвования института самодержиа 1812-1858: К типологии основ имперского управления, Helsinki, 1998, с. 289).

42. В пользу подобной мотивации свидетельствуют особенности биографий двух молодых людей, которых Радеку было разрешено взять себе в помощники. Один из них, подписывавший документы как М. Зарецкий, вероятно, может быть отождествлен с пользовавшимся этим псевдонимом белорусским литератором Михаилом Косенковым (1901-1937), который в 1929 г. был исключен из ВКП(б), хотя и продолжал печататься. Другим был колоритный Александр Тивель (Левит) (18991937), успевший побывать анархистом, эмиссаром Коминтерна в Центральной Азии и, главное, секретарем Зиновьева. Вспоминая жизненные перипетии секретарей Троцкого, можно предположить, что это обстоятельство сильно сказалась на положении Тивеля в конце 20-х-начале 30-х гг.

43. Протокол заседания Политбюро ЦК ВКП(б) № 5 от 25.8.1930, РГАСПИ, /17/3/793/15

44. «Организационно проведение этой кампании» было поручено Радеку наравне с Заведующим Отделом пропаганды и агитации ЦК ВКП(б) Стецким (Протокол заседания Политбюро ЦК ВКП(б) № 26 от 15.2.31, там же, /17/3/813/15).

45. Протокол заседания Политбюро ЦК ВКП(б) № 87 от 8.2.32, там же, $/ 17 / 162 / 11 / 174$

46. Записка И. М. Гронского Секретарю ЦК ВКП(б) И. В. Сталину, 20.4.1932, там же, /17/114/297/163об

47. Протокол заседания Политбюро ЦК ВКП(б) № 98 от 4.5.1932, там же, /17/162/12/113. «Дело», возможно, касалось советско-американских военных контактов (см.: В. П. Сафронов, СССР, США и японская агрессия на Дальнем Востоке и Тихом океане, 1931-1945 г2., М., 2001, с. 369; «Письмо К. Е. Ворошилова И. В. Сталину, 6.6.1932», А. В. Квашонкин и др., сост., Советское руководство. Переписка. 1928-1941, М., 1999, с. 173-174). 


\section{Организация БМИ и начало его деятельности (весна - осень 1932 г.)}

В середине мая 1932 г. высшее партийное руководство без возражений утвердило предложения Радека и Стецкого о задачах Бюро. Ему поручалось сосредоточить в своих руках «информацию по международным делам, приходящим в ЦК ВКП(б) по всем каналам наших учреждений» (как советских, так и партийных) $)^{48}$. БМИ получил право требовать у этих учреждений дополнительных «объяснений» и специальной «разработки» интересующего Бюро вопроса. Создаваемый мозговой трест кроме того, должен был дополнять информацию других органов и ведомств сведениями, самостоятельно извлекаемыми из «иностранной прессы и литературы», а также наладить «получение сведений из иностранных источников». Последнее подразумевало, что сотрудники БМИ уполномочены устанавливать прямые контакты с дипломатами и иными представителями политических, хозяйственных и военных кругов зарубежных стран, что подтверждалось в указании проверять «результаты всей предыдущей работы» через направляемых за границу агентов («собственных корреспондентов»).

Информационно-аналитические заключения Бюро предназначались для «ежедневной информации ЦК» по текущим делам, подготовки «новых, крупных вопросов, в данный момент не решаемых», а также - «по указаниям секретариата ЦК» (т.е. Сталина) — для инспирирования публикаций в советской прессе. Тематически сфера деятельности БМИ была не ограничена, однако в ближайшие месяцы должна была концентрироваться вокруг трех основных проблем: (а) взаимных отношений СССР, Польши и Германии; (б) перспектив политики стран Центральной Европы в отношении СССР и «организующей роли Франции», и (в) японо-американских и японо-советских отношенияй.

Новому органу, наделенному небывалыми полномочиями, предписывалось вести существование не только в секрете, но и поистине виртуально. Во-первых, Бюро международной информации не подчинялось какому-либо Отделу или руководящему органу Центрального комитета, будь то Политбюро или Секретариат. Единственной структурой ЦК, с которой БМИ предписывалось взаимодействовать, являлось Управление делами (и лишь для того, чтобы «совместно» с ним установить «бюджет московского аппарата»). Во-вторых, своеобразная хартия Бюро, выданная ему политическим руководством, определяла, что «БМИ создает только небольшой подсобный аппарат» и «не развертывает постоянных кадров собственных сотрудников», за исключением «кадра разъездных корреспондентов, которые на основе своего знания, специальных связей могут, когда надо непосредственно проверить наши суждения». Местоимение первого лица, нео-

48. Стремление Радека реализовать это право встречало (по крайней мере, поначалу) сопротивление в аппарате ЦК (см.: «Письмо Л. М. Кагановича И. В. Сталину, 26.6. [1932]», О. В. Хлевнюк и др., сост., Сталин и Каганович. Переписка, 1931-1936 г2., M., 2001, c. 196). 
жиданно ворвавшееся в перечень прав и обязанностей Бюро (и столь характерное для объявления монаршей воли), выдавало происхождение создаваемой структуры. Другие пункты документа прямо называли источник и пределы власти БМИ: «Список спецкоров на ближайшие месяцы утверждается тов. Сталиным», их «каждая поездка будет согласована с т. Сталиным». Вероятно, для того, чтобы предупредить возражение партийных олигархов, что деятельность разъезжающих по Европе агентов Сталина может нарушить заведенный порядок, специально оговаривалось: они «не имеют никаких оперативных задач, не могут вмешиваться в работу наших учреждений заграницей, не передают никаких директив», «они только наблюдатели, которые должны на месте изучить положение и доложить о результатах своей работы». Эти постоянные сотрудники БМИ должны были действовать под маской специальных корреспондентов Известий ${ }^{49}$.

Тема расширения корреспондентской сети Известий и назначения специальных корреспондентов появилась в переписке редакции с Секретариатом ЦК в начале апреля 1932 г., т.е. сразу после принятия решения о создании БМИ. Наряду с сотрудниками газеты (бывшим членом Компартии Польши П. Лапинским (Левинсоном), членом Компартии Болгарии Степняком), и известным французским коммунистом Ж. Садулем, на роли новых корреспондентов прочили помощника заведующего Отдела печати НКИД Я. Подольского и бывшего референта Восточного отдела НКИД А. Канторовича. Специальным корреспондентом «для Японии и Китая» предлагалось назначить К. Радека, а «для Западной Европы» - С. Раевского $^{50}$. Ссылаясь на материалы ОГПУ и прегрешения перед партией Организационно-распределительный отдел ЦК дал отвод Канторовичу (бывший меньшевик) и Подольскому (связан с антисоветски настроенными иностранными корреспондентами, исключался из партии за пассивность), и Оргбюро не утвердило их назначения. Логика аппаратчиков наиболее ясно проявилась в протесте против кандидатуры Раевского, ибо «он только в 29 году вернулся из заграницы (Париж)»; знакомства в зарубежных политических кругах у него действительно имеются, «но, по данным ГПУ, с лицами, связь с которыми не характеризует Раевского с положительной стороны» ${ }^{51}$. Из этого заключения следовало, что для активных информационных задач лучше посылать человека, давно не покидавшего пределов

49. Постановление Политбюро ЦК ВКП(б) «Об информационном бюро», 16.5.1932, РГАСПИ, /17/162/11/143-144 (опубликовано: О. Н. Кен, А. И. Рупасов, указ. соч, c. $566-568)$.

50. Записка Ответственного редактора Известий И. М. Гронского Секретарям ЦК ВКП(б) И. В. Сталину, Л. М. Кагановичу, П. П. Постышеву, 5.4.1932, там же, /17/114/297/162 (неясно, было ли это предложение согласовано с заведующим Отделом культуры и пропаганды ЦК ВКП(б) А. Стецким: под письмом Секретарям ЦК оставлено место для его подписи, но она отсутствует).

51. См.: Записка сотрудника Организационно-распределительного отдела ЦК ВКП (б) А. Гусева Секретарю ЦК ВКП(б) Л. М. Кагановичу, [конец апреля — начало мая 1932 г.], там же, /17/114/247/161-161об. 
СССР и имеющего знакомых исключительно среди твердых ленинцев ${ }^{52}$. Сталин так не считал, и решение о назначении как Радека, так и Раевского в первой половине мая было проведено через партийные инстанции.

Иностранный отдел Известий служил не только основным поставщиком кадров БМИ, но и легальным прикрытием его секретной деятельности. Сам Радек оставался членом редколегии Известий ${ }^{53}$. «Ввиду того, что не всегда желательно, чтобы работающий знал, что работает для БМИ», финансирование поездок за границу и подготовки в Москве аналитических материалов и статей было решено осуществлять через фиктивные банковские счета, принадлежащие, якобы, Иностранному отделу Известий 54 . Можно сказать, что создание Бюро международной информации официально оформило международно-политические функции сотрудников Известий, которыми они в действительности наделялись и ранее.

Привлечение журналистов для информирования дипломатических ведомств (и использование ими органов печати) было весьма распространено в межвоенной Европе 55 . Однако развертывание сети зарубежных корреспондентов для выполнения, наряду с прочими функциями, специальных заданий «в ситуациях, при которых использование официальных каналов было невозможно или нежелательно» ${ }^{56}$, было, пожалуй, изобретением режима Пилсудского, склонного к старым методам конспирации и пренебрежительно относившегося к формальным политическим и дипломатическим процедурам. Элементы аналогичной практики существовали и в Советской России 20-х гг., но ее институциональное оформление путем создания Бюро международной информации стало качественно новым явлением. Своим появлением оно, думается, немало обязано воздействию двух импонирующих примеров - классического и современного. Первым из них являлся ленинский проект создания общенациональной партии на основе деятельности газеты Искра, агенты которой одновременно со сбором информации налаживали связи между социал-демократическими группами. Этот опыт прекрасно корреспондировал с новейшим польским knowhow, о котором мог поведать Сталину Радек, специально изучавший

52. Любопытно, что аппарат не оспаривал выдвижение Радека на роль «спецкора»: по всей вероятности, его тесная связь со Сталиным исключала такую возможность.

53. Впрочем, неискушенная в политике бухгалтерия газеты отметила в его учетной карте, что с июля 1932 г. Радек перестал получать там зарплату (Учетная карточка К. Б. Радека, 1932-1933. - Архив издательского комбината «Известия». Национальность Радека в этом документе была указана как «поляк»).

54. Утвержденная позднее смета валютных расходов БМИ составила: на 1933 г. - 9,5 тыс. зол. рублей, на 1934 г. - 10 тыс. зол. рублей (Протокол заседания Политбюро ЦК ВКП(б) № 134 (особый) от 4.4.1932, РГАСПИ, /17/162/14/106; Протокол заседания Политбюро ЦК ВКП(б) № 152 (особый) от 20.1.1934, там же, /17/162/15/164).

55. Достаточно, например, вспомнить об интимных связях между Northern Department of the Foreign Office и корреспондентом Times В. Поляковым (Augur) - отцом французской актрисы Марины Влади.

56. Piotr Łossowski, red., Historia dyplomacji polskiej, Warszawa, 1993, s. 473. См. также: Arkadiusz Adamczyk, Bogusław Miedziński (1891-1972): Biografia polityczna, Praca doktorska (Uniwersytet Łódzski, 1998), s. 203, 214. 
политические методы Пилсудского и знакомый с западной журналистской средой.

Вместе с тем появление новой структуры создавало противовес политическому влиянию ответственного секретаря Известий Ивана Гронского, основанного на его близости к Сталину как консультанта и исполнителя (в 1932 г. это влияние было столь значительно, что, по воспоминаниям Гронского, нарком Литвинов порой просил последнего устроить ему личную встречу со Сталиным) ${ }^{57}$. Доклады польского военного атташе в Москве (с которым в конце 1932 г. Радек и Гронский вели интенсивные зондажные беседы) свидетельствуют о наметившемся соперничестве между ними. «Вот Радек - он у нас симпатизирует немцам, а я наоборот, я симпатизирую полякам, - передавал атташе слова Гронского на приеме в польской миссии. - (Радек зло смеется)». Позже Радек подошел к атташе, чтобы узнать, «жив ли он после этой интенсивной беседы с Гронским. Он ведь из дикой дивизии...»58. «Радек в целом произвел на меня впечатление гораздо менее уверенного в себе, чем обычно, - резюмировал проницательный атташе. - Он выглядел так, будто недавно проиграл какую-то дискуссию» 59. Самого Гронского, в прошлом рабочего и комиссара гражданской войны, Я. Ковалевский характеризовал как «человека простоватого (nieskomplikowany), но с огромным темпераментом», ведомого «не столько рациональным пониманием, сколько чувством», порой поражающего своей искренностью ${ }^{60}$. В 1933 г., по мере развертывания деятельности Бюро, роль Гронского в международных делах становится незаметной; в феврале 1934 г. от теряет пост ответственного редактора Известий и становится главным редактором журнала Новый мир (1934-1938).

Судя по немногочисленным свидетельствам о деятельности БМИ, в первые полтора года (лето 1932 - начало 1934 г.) она была сосредоточена, как и предусматривалось при создании Бюро, главным образом на политических и военно-стратегических проблемах взаимоотношений в треугольнике Москва-Варшава-Берлин. В августе 1932 г. для зондирования позиций германских политических кругов Радек и Лапинский совершили конфиденциальную поездку в Берлин ${ }^{61}$; тремя месяцами позже Раевский посетил польскую столицу, где встречался, в частности, с И. Матушевским - специальным уполномоченным Пилсудского. (В апреле 1932 г. польский диктатор поручил Игнацию Матушевскому и Богуславу Медзиньскому наладить неофициальный контакт с советским полпредством в Варшаве ${ }^{62}$. Каждый из них в прошлом занимал посты руководителя

57. И. М. Гронский, Из прошлого: воспоминания, М., 1991, с. 147.

58. В молодости Гронский служил в Дикой дивизии, квартировавшей тогда в Варшаве.

59. Raport attaché wojskowego RP w Moskwie J. Kowalewskiego do Szefa Oddziału II Sztabu Głównego Т. Pelczyńskiego, Moskwa, 22.11.1932, ЦХИДК, /308/12/120/62,64.

60. List J. Kowalewskiego do Т. Pelczyńskiego, Moskwa, 20.12.1932, ЦХИДК, $1308 / 12 / 120 / 80$

61. См.: Дневник советника полпредства СССР в Германии С. Ф. Виноградова, 20.8.1932, АВП /082/15/68/7/496.

62. «Bogusław Miedziński. Pakty Wilanowskie», Kultura, n 189-190, 1963, p. 113. 
военной разведки и министра финансов, с начала $30-\mathrm{x}$ гг. они являлись фактическими со-редакторами проправительственной Gazeta Polska). Раевский вернулся в Москву с убеждением о серьезном сдвиге польского правительства «К миролюбивой политике в отношении нас» 63 . Действительно, ратификация договора о ненападении между СССР и Польшей, на которую она пошла несмотря на разрыв переговоров СССР с польской союзницей - Румынией, произвела в Москве сильное впечатление. В два последних месяца 1932 г. общение советских журналистов (Радека, Гронского, Раевского, Подольского и др.) с польской миссией в Москве стало крайне насыщенным (один из таких «завтраков» в миссии продолжался с половины первого до восьми часов вечера). Советские представители расточали необычайные похвалы польскому государственному гению («из ничего сделали государство, крепкое, большое государство, которое нас побило в двадцатом году», говорил Гронский, «из развалин действительно построили новую, бойкую, сильную и красивую жизнь в Польше» 64 ) и провозглашали тосты за здоровье Пилсудского («Господин генерал может доложить господину Маршалу, что он имеет поклонников в лице представителей официальной советской печати», — писал в Варшаву военный атташе $\left.{ }^{65}\right)$. «И я говорю еще больше, что мы польскую независимость должны не только уважать, что нашей политикой мы должны, мы обязаны ее охранять», - запальчиво заявлял Гронскийб6. Радек вспоминал о том, как в 1920 г. тщетно убеждал Ленина не переходить Буг, и размышлял над тем, как опасно снова утратить возможность позитивного взаимодействия Москвы и Варшавы: «... посмотрите на Польшу, посмотрите на Германию. - Поразмыслив, каждый сам придет к выводу, какими могут быть варианты наших политических концепций». Радек и его коллеги при этом намекали, что высказываемые ими взгляды разделяются Сталиным и прямо предлагали полякам посредничество, позволяющее обойти Наркоминдел и официальные инстанции. «Радек и Раевский все время ссылаются на то, что часто видят Сталина и что через них можно обращаться непосредственно к нему. Они всегда говорят: «Только скажите, какое у вас дело — и оно напрямую окажется у Сталина» («Mówcie tylko o co wam chodzi — trafi do Stalina wprost» $)^{67}$.

63. Письмо полпреда СССР в Варшаве В. А. Антонова-Овсеенко Члену Коллегии НКИД Б. С. Стомонякову, 7.10.1932, АВП /0122/16/159a/17/180.

64. Raport J. Kowalewskiego do Т. Pelczyńskiego, Moskwa, 22.11.1932, ЦХИДК, /308/12/120/61-62.

65. List J. Kowalewskiego do T. Pelczyńskiego, Moskwa, 20.12.1932, там же, 1308/12/120/80.

66. Raport J. Kowalewskiego do T. Pelcyńskiego, Moskwa, 22.11.1932, там же, 1308/12/120/61-62.

67. Поначалу в польской дипломатической миссии не вполне осознавали, что речь о серьезных попытках наладить новый канал связи, о большой политической игре, и были склонны объяснять поведение представителей неведомого Бюро карьерными соображениями. «Здесь полагают, — сообщал Ковалевский, — что они главным образом желают заполучить что-то, с чем можно было пойти к Сталину, который, должно быть, любит сведения, поступающие вне заведенного порядка (poufale). Он потом указывает им что-то инспирировать, таким образом можно сыграть при 
Таким образом, уже к началу 1933 г. деятельность руководителей Бюро международной информации вышла за пределы, очерченные в постановлении Политбюро мая 1932 г., согласно которому в полномочия Бюро отнюдь не входило информирование западных правительств о направлении, в котором развивается советская внешняя политика, ни, тем более, установление неофициальных связей Кремля с их представителями. Замысел Сталина, в конце осени 1931 г. приступившего к реформированию механизмов формирования советской внешней политики, тем самым выявился с большей полнотой. Наряду с передачей ключевых политических проблем на усмотрение узкой комиссии Политбюро и формированием собственной информационно-аналитической сверхструктуры Сталин выпустил на арену тайной дипломатии своих агентов. Публичная миссия члена редакционной коллегии Известий и секретные функции сотрудника БМИ при ЦК ВКП(б) для Радека и Раевского являлись по существу второстепенными по отношению к их основной роли личных агентов Сталина, не скованных ни ведомственной иерархией и партийной дисциплиной, ни дипломатическими условностями и обязательствами.

\section{БМИ и сближение с Польшей (зима, весна и лето 1933 г.)}

Конец 1932 - начало 1933 гг. ознаменовались глубокими сдвигами в постВерсальской системе международных отношений. Осенью 1932 г. Германия, требуя равноправия в вооружениях, покинула Лигу Наций и согласилась вернуться в нее после обещания западных держав удовлетворить это требование в рамках системы безопасности. Страны Восточной Европы, лишенные даже той призрачной защиты против германского ревизионизма и экспансии, которую предоставили Франции и Бельгии Локарнские соглашения стояли перед выбором: следовать за слабеющей Франции или искать собственные пути во внешней политике. Приход к власти национал-социалистов резко обострил международное положение Польши, традиционно являвшейся главной мишенью германского экспансионизма.

Советский Союз оказывался в небывало выгодной для себя дипломатической ситуации. В Москве были искренно озабочены антисоветскими эксцессами германской «революции» и планами германской экспансии на Украину, но по своему опыту хорошо знали, сколь велика дистанция отделяющая революционную идеологию от реальной политики, тем более что министра рейхсвера в Наркоминделе считали «нашим другом», а рейхсканцлер через посредников, в беседе с полпредом СССР и даже публично заявлял о единстве стратегических интересов Германии и России. Прибегая к излюбленным диалектическим приемам, советские деятели охотно указывали на то, что нарастание противоречий между капитали-

Сталине определенную роль - что крайне выгодно с точки зрения престижа» (Rozmowa podpułkownika J. Kowalewskiego z redaktorem Izwiestij Gronskim w dniu 7 listopada 1932 roku na przyjęciu u Kalinina, ЦХИДК, /308/12/120/64). 
стическими странами чревато созданием антисоветского блока этих государств; в действительности Москва получила возможность играть на этих противоречиях. Советская пропаганда продолжала негодовать против грабительского Версальского мира, создавшего на западных рубежах СССР «санитарный кордон» малых восточноевропейских государств, однако в Кремле осознавали, что от его действий решающим образом зависит, превратится ли обветшалый кордон в стену, защищающую границы СССР от Балтики до Черного моря, либо окончательно распадется благодаря советско-германскому сотрудничеству. На протяжении 1933 г. в советской политике постепенно нарастала дихотомия между формирующимся курсом на коллективную безопасность и обновленной антиверсальской стратегией, причем обе ориентации подпитывали друг друга (так, советские заявления в пользу европейского статус-кво стимулировали интерес Берлина к возобновлению диалога с Москвой, а призрак нового Рапалло побуждал Францию двигаться к договору с СССР о mutuelle assistance).

Конечная реализация любой из двух перспектив, открывавшихся перед Советским Союзом (участие в переделе Европы и его предотвращение в интересах сохранения мира), и даже сохранение положения, при котором выбор между ними мог быть, к немалой выгоде для себя, отсрочен, зависела от состояния отношений с Польшей и ее политического курса. Пойдет ли она, в надежде на последующую компенсацию за счет СССР, на компромисс с Германией или же решится противостоять ей и в своем сопротивлении опереться на большевистскую Россию? Этот вопрос, неразрывно связанный с разработкой польской политики Кремля, превратился в главный для Бюро международной информации. Приоткрывая свои размышления (и стремясь выяснить реакцию поляков) в феврале 1933 г. К. Радек на страницах журнала ЦК ВКП(б) рассмотрел возможность «исправления» польско-германской границы и получения Польшей компенсации за передачу Коридора Германии в виде экспансии на Украине или получения выхода к морю через Мемель. Изложив все отрицательные для Польши стороны такой сделки, Радек заключал: «...отказ от Приморья для достижения компромисса с Германией был бы началом раздела Польии. Польская буржуазия вряд ли пойдет добровольно на подобный “обмен”...»68. Одновременно «Радек и другие» в беседах с польским военным атташе Ковалевским (имевшим право личного доклада Пилсудскому) давали понять, что Кремль готов поддержать решительный отказ Польши от территориальный уступок Германии ${ }^{69}$. В марте 1933 г., вслед за началом переговоров о «пакте четырех держав», который выглядел по меньшей мере моральной поддержкой итало-германского ревизионизма со стороны Франции и Великобритании, С. Раевский вновь заверил возвращавшегося в Варшаву Ковалевского в том, что Пилсудский пользуется большим уважением Сталина, что другие государственные

68. К. Радек, «Новый этап фашизации Германии», Большевик, № 3, 1933, с. 54. 69. Дневник полпреда СССР в Варшаве В. А. Антонова-Овсеенко, 15.3.1933, АВП, /0122/17/164/5/168 
деятели и даже Красная Армия настроены полонофильски. В ходе этой ответственной беседы Раевский пошел гораздо дальше предыдущих обменов взглядами, заявив, что ситуация созрела для заключения Польшей и Францией союза с СССР против Германии. Руководство Красной Армии очень желает установить близкие отношения с польским командованием, но боится, что его инициатива не встретит позитивного отклика. Между тем, в случае польско-германской войны, утверждал Раевский, Советский Союз готов не только соблюдать нейтралитет (что предусматривалось советскопольским договором 1932 г.), но и поставлять Польше вооружения и военные материалы ${ }^{70}$. Польскому представителю пришлось услышать даже, что «фронт Советского Союза сейчас [находится. - Авт.] на Прасне и Варте», реках польско-германского приграничья ${ }^{71}$.

Двусмысленность этой формулы и рискованность военно-политической договоренности с СССР, разумеется, не укрылись от высшего польского руководства, но оно с понятным удовлетворением публично отреагировало на советские заверения. 27 марта Gazeta Polska заявила о готовности сотрудничать с СССР и Малой Антантой в интересах поддержания стабильности в Центрально-Восточной Европе. Вслед за этим советский посланник Антонов-Овсеенко дал понять редактору Gazeta Polska (и неформальному дирижеру всей правительственной прессы) Медзиньскому, что неофициальные беседы следовало бы продолжить на ином уровне. Сторонник сближения СССР с Польшей, Антонов-Овсеенко с конца 1930 г. находился в конфликте - то явном, то скрытом - с руководством НКИД по главным вопросам двусторонних отношений. Для поляков он часто оказывался неуступчивым партнером и трудным собеседником, однако в Варшаве помнили, что тремя десятилетиями раньше будущий революционер - молодой поручик царской армии не раз демонстративно отдавал саблей торжественный салют памятнику Мицкевича (за что был отправлен служить в провинциальный гарнизон «русской» Польши, где в 1905 г. попытался поднять восстание). На рубеже 1923-1924 гг. Антонова сблизила с Радеком общая бескомпромиссная позиция во внутрипартийном кризисе; теперь, когда они оба тесно сотрудничали со Сталиным (АнтоновОвсеенко был одним из немногих дипломатов, периодически встречавшихся со Сталиным), уважение к Радеку у него сохранилось. Есть и другие основания полагать, что совет, который варшавский полпред дал представителю Пилсудского, был инспирирован заведующим БМИ.

На протяжении полугода главным партнером Радека, Раевского и Гронского являлся военный атташе подполковник Ян Ковалевский, искушенный разведчик и дипломат, за четыре года пребывания в Москве

70. Michał Jerzy Zacharias, «Polska wobec zmian w układzie sił politycznych w Europie w latach 1932-1936», Wrocław etc., 1981, s. 83.

71. Дневник полпреда СССР в Варшаве В. А. Антонова-Овсеенко, 15.3.1933, АВП, /0122/17/164/5/168. 
хорошо изучивший советскую сцену ${ }^{72}$. Не менее важно, что Ковалевский по существу являлся представителем Пилсудского (официально занимавшего пост военного министра Польши) и пользовался его доверием. В феврале 1933 г. ОГПУ, с большой неохотой согласившееся на его назначение военным атташе и не раз предлагавшего удалить Ковалевского из Москвы, вновь заявило о необходимости его высылки, с чем на этот раз согласилось и руководство НКИД. Обвинения против польского атташе были довольно туманны, одно из них было основано на сведениях о «разговорах между Ковалевским и японским военным атташе, которые трудно было не квалифицировать как поощрение японской агрессии» ${ }^{73}$. Еще лучше ОГПУ и НКИД должно было быть известно о контактах Ковалевского со сталинскими «спецкорами». Удаление из Москвы их главного контрагента нарушало затеянную по заданию Сталина игру и стало, вероятно, первым серьезным столкновением интересов Бюро международной информации ЦК ВКП(б) и авторитетных государственных инстанций. Радеку (и его хозяину) в начале весны 1933 г. требовалось срочно восстановить контакт с Бельведером, и полковник Медзиньский (незнакомый с Радеком лично, но уже год обхаживавший полпреда Антонова) оказался как нельзя более кстати. «Mystérieux et méfiant, paraissant conspirer toujours» ${ }^{74}$, Медзиньский сочетал в себе преданность национальным идеалам и лично Пилсудскому с развитым критическим мышлением, способностью к самостоятельной оценке новых задач ${ }^{75}$.

Отвечая на пожелание Москвы, Пилсудский поручил Медзиньскому отправиться в советскую столицу, и уже 30 апреля Радек приветствовал польского гостя на Белорусском вокзале. Объявленной целью визита являлось установление рабочих контактов между органами печати двух стран, что создавало отличный повод для конфиденциального контакта «двух старых политиков, знающих друг о друге, кого они представляют». Главной задачей полковника Медзиньского было передать твердое заверение Пилсудского: «Польша никоим образом и ни при каких обстоятельствах не свяжется с Германией против Советского Союза» и убедить собеседника в том, что эта позиция отражает императив польского raison d'État. Если советская сторона этой поймет, закончил эмиссар, дорога к лучшему формированию отношений Москвы и Варшавы открыта. Сле-

72. Через тридцать лет его познаниям воздаст должное автор непревзойденного труда о Красной Армии (John Erickson, Soviet high command : A military-political history, 19181941, L., 1962, p. 15).

73. См.: Дневник Члена Коллегии НКИД Б. С. Стомонякова. Прием военного атташе польской миссии 5.4.1933, АВП, /0122/17/164/4/301-309; Дневник Наркома иностранных дел М. М. Литвинова. Прием Лукасевича 19.4.1933, АВП, /0122/17/164/4/290

74. Leon Noël, Polonia restituta: La Pologne entre deux mondes, Paris, 1984, p. 107. «У Медзиньского есть привычка к созданию в конспирации еще одной конспирации», говорил знающий в этом толк Ю. Пилсудский (Kazimierz Switalski. Diariusz 1919-1935, Warszawa, 1992, s. 354).

75. Благодарю госпожу Anna Radomyska, беседа с которой в июне 1999 г. позволила лучше понять незаурядную личность ее отца Б. Медзиньского. 
дующей ночью Радек позвонил Яну Берсону (московскому корреспонденту Gazeta Polska), чтобы тот передал своему шефу: «Значение Вашего приезда и наших бесед получило должную оценку. Если Вы немного задержитесь в Москве, то будет возможен Ваш прием Иосифом Виссарионовичем». Генеральный секретарь, насколько мы можем судить, никогда прежде не виделся с неофициальными представителями иностранных правительств (некоммунистических иностранцев, которых он принял к тому времени, вообще можно пересчитать на пальцах), и неудивительно, что посланец Пилсудского к такой возможности был совершенно не готов. Беседы со Сталиным Медзиньский «попросту боялся: не Сталина, конечно, а Пилсудского и своей собственной неподготовленности», и потому уклонился от встречи с кремлевским диктатором, вместо этого пригласив Радека в Польшу для продолжения обмена мнениями ${ }^{76}$.

После отъезда Медзиньского Радек побывал у Сталина, чтобы доложить о содержании состоявшихся бесед о «серьезном сотрудничестве в области международной политики». «Сталин поручил ему сообщить, что принимает эти предложения, и выразил сожаления, что г-н министр так быстро покинул Москву». Передав Берсону это устное послание, Радек взял с него офицерское слово чести, что тот передаст его только Медзиньскому, и «просил о сохранении в дальнейшем секретности», в особенности напирая на неупоминание имени Сталина ${ }^{77}$. Одновременно заведующий БМИ, по всей вероятности, получил задание об углубленной разработке польскогерманских проблем. До конца мая Бюро международной информации представило два важных доклада - «Борьба за ревизию Версальского договора и сдвиги во внешней политике Польши» и «разработанный группой товарищей, имеющих специальные знания в этой области», обширный доклад «Экономическое и стратегическое значение Коридора», к которому прилагались карты дислокации польской и немецкой армий и схема развертывания польской армии по предположениям рейхсвера ${ }^{78}$. В первом из них обосновывалась мысль о том, что с 1932 г. из-за растущих

76. Bogusław Miedziński, «Droga do Moskwy», Kultura, n 188, 1963, s. 84-86. Освещение визита Медзиньского со стороны НКИД см.: Дневник Члена Коллегии НКИД Б. С. Стомонякова. Разговоры с Медзиньским, [1-4.5.1933], АВП, /0122/17/164/4/248-250.

77. List J. Bersona (Otmara) do «Pana Ministra» [B. Miedzińskiego], Moskwa, 1.6.1933 (odpis), AAN, /MSZ/6748a/57-58. По словам Радека, его беседа со Сталиным состоялась на следующий день после отъезда Медзиньского, т.е. 7 мая. В журнале посетителей кабинета Генерального секретаря за 8 мая отмечено 45-минутное пребывание там Радека в обществе Сталина, Молотова и Кагановича. Неясно, идет ли речь об одной и той же встрече.

78. Доклад Бюро международной информации № 55 (по Польше № 3) «Борьба за ревизию Версальского договора и сдвиги во внешней политике Польши», 16.5.1933 (подписан помощником Заведующего БМИ Зарецким), АВП, /010/7/24/12/17-35; Доклад Бюро международной информации № 56 «Экономическое и стратегическое значение Коридора», 26.5.1933 (с сопроводительной Заведующего БМИ), там же, /010/7/24/12/36-63 (приложения отсутствуют). Эти доклады изготовлялись в том же примерно количестве (24 экземпляра), что и материалы к заседаниям Политбюро; список их рассылки неизвестен, обнаруженные экземпляры находятся в делах Секретариата Заместителя наркома Крестинского. 
противоречий с Германией и внутреннего укрепления СССР Пилсудский временно отказался от активной антисоветской политики и «считает, что ближайшее столкновение должно произойти на западных границах Польши и лишь после успеха в этой войне Польша сможет вернуться к непосредственной подготовке своей экспансии на восток». Доклад военных специалистов приводил к заключению, что контроль над Коридором имеет прежде всего стратегическое значение и передача его Германии «не может быть приемлемым для Польши». С другой стороны, поляки способны («в порядке превентивной войны») без труда овладеть Восточной Пруссией, но через несколько месяцев после начала войны их подавляющее военное превосходство над немцами будет утрачено. Возможно, именно эти соображения были предметом краткой беседы Радека со Сталиным, Молотовым, Кагановичем и Микояном 26 мая 1933 г. ${ }^{79}$. В сжатом и упрощенном виде они были немедленно вынесены на страницы партийной печати. «Владение Польским коридором обеспечивает стратегическую инициативу Польши в случае войны в смысле выступления на Берлин, - заявил орган ЦК ВКП(б). - Переход Польского коридора к Германии обеспечивал бы последней стратегическую инициативу в случае войны в смысле выступления на Варшаву.» 80

Анализ ситуации, проведенный Бюро с участием специалистов из Штаба РККА, был ориентирован на военный по своей природе (и в целом характерный для советского военно-политического мышления) концепт «соотношения сил». «Все политические концепции Радека, - подметил польский военный атташе, - всегда и постоянно имеют военную подкладку и окраску». Он объяснял это «психологическим складом Радека, коминтерновца и бывшего активного троцкиста, который пошел на соглашение со сталинским мирным курсом, но, понимая необходимость “передышки”, считает ее временным периодом истории коммунизма» 81 . Очевидная слабость этого анализа (и параллельной ему неофициальной дипломатии) состояла в ориентации на конечную развязку, которую все конфликтующие стороны были вынуждены оттягивать. Тем самым в стороне оставлялась реальная перспектива временного и частичного политического урегулирования польско-германских противоречий, к которой с весны 1933 г. стали склоняться как Пилсудский, так и Гитлер. К оттягиванию

79. Посетители, с. 146.

80. Л. Мадьяр, «Фашизм и опасность войны», Больщевик, № 9, 1933, с. 27. Симметричное строение абзаца, упрощенность оппозиции и нетронутая редактором легкая неправильность языка позволяют предположить, что автором этого пассажа мог быть Сталин (не раз лично правивший статьи по международным проблемам перед их публикацией в советской печати), тем более, что номер был сдан в набор с двухнедельной задержкой - 27 мая. Основной текст доклада был опубликован под псевдонимом «Дуо» и аутентичным названием в сентябре 1933 г. в органе ЦК ВКП(б) (Большевик, № 15-16, 1933, с. 20-30).

81. Raport attaché wojskowego RP w Moskwie J. Kowalewskiego do Szefa Oddziału II Sztabu G łównego Т. Pelczyńskiego, Moskwa, 22.11.1932, ЦХИДК, /308/12/120/65-68. О «милитаризованности» высказываний Радека см. также: J. Payart à E. Herriot, Moscou, 4.11.1932 Documents diplomatiques français [далеe - DDF], 1-re sér. t. I: 9 juillet 14 nov. 1932, Paris, 1964, p. 685. 
политического решения о позиции Советского Союза и сохранению свободы рук стремились и сами советские вожди, желая, однако, свести к минимуму такую возможность для главного западного соседа - Польши.

Другим коренным препятствием к сотрудничеству СССР и Польши являлась украинская проблема. С конца 1933 г. Москва развернула кампанию по выкорчевыванию остатков национального коммунизма на Советской Украине и превращению ее в обращенный на Запад «форпост великого СССР». Ответственность за сопротивление проводимой унификации («большевистской украинизации») руководство ВКП(б) и КП(б)У в значительной мере возлагали на польские власти, якобы инспирировавшие антисоветские и националистические акции общественно-политических украинских партий восточных воеводств Польши. Даже террористическая деятельность Организации украинских националистов и ее боевого крыла (от рук которых в 1934 г. погибнет польский министр внутренних дел) изображалась как порождение «польской охранки» 82 . В конце мая заведующий БМИ встретился с Яном Берсоном, на которого Варшава возложила функции liaison officer по контактам с Радеком. Сообщив, что Сталин разрешил ему в любой момент выехать в Польшу, Радек «поднял украинскую проблему» и заявил (несомненно, по поручению своего шефа): «Какая-либо ваша [поляков. - Авт.] активность на этой территории будет нами комментироваться как сознательное или бессознательное выполнение немецких планов на востоке» 83 .

По всей вероятности, именно в том духе - одновременно дружественном и ультимативном по отношению к польской политике - было выдержано напутствие, полученное Радеком 28 июня от членов Комиссии по международным делам (Сталин, Молотов, Каганович) ${ }^{84}$. Спустя неделю Радек прибыл в Варшаву. Насыщенная шестнадцатидневная программа его пребывания в Польше включала многочисленные встречи с политиками, военными, журналистами и дипломатами (том числе министром и вицеминистром иностранных дел). Руководители НКИД, будучи лишь частично осведомлены о задании Радека, считали целью поездки сбор сведений и выражали надежду, что «благодаря его связям и особому к нему отношению, мы получим через него ценную информацию о настроениях в правящих польских кругах в отношении СССР, Германии и других стран» 85 .

82. См.: Oleg Ken, Collective security or isolation? op. cit., p. 98-99.

83. List J. Bersona (Otmara) do «Pana Ministra» [B. Miedzińskiego], Moskwa, 1.6.1933 (odpis), AAN/MSZ, /6748a/57. Другой вариант заявления Радека (вероятно, повторенного им в Варшаве): «О вашем отношении к нам и немцам мы будем судить о "работе" вашей в Сов[етской] Украине» (Запись беседы полпреда СССР в Варшаве В. А. Антонова-Овсеенко с посланником Польши в Москве Ю. Лукасевичем, Москва, 3.12.1933, АВП, /0122/17/164/4/38).

84. Посетители, с. 183-184. В этой беседе, надо думать, Радек поднял и «кадровый вопрос», и по его запросу 1 июля Политбюро распорядилось направить на работу в БМИ сотрудника Ленинградского ОГПУ Е. Жукова (будущего академика востоковеда) и венгра-коминтерновца Аквилу (Дьюлу Шаша) (Протокол заседания Политбюро ЦК ВКП(б) № 140 от 1.7.1933, РГАСПИ/17/3/925/20).

85. Письмо Члена Коллегии НКИД Б. С. Стомонякова полпреду СССР в Варшаве В. А. Антонову-Овсеенко, 4.7.1933, АВП, /0122/17/164/2/82. 
Между тем, в первый же день пребывания в Варшаве Радек сообщил Медзиньскому о желании продолжить серьезный обмен мнений: «теперь он явно имел на то полномочия от Сталина» 86 . Прежде, чем начались серьезные переговоры, Радек воспользовался предоставленной ему возможностью совершить поездку в Поморье (где он сделал широковещательные заявления о важности укрепления выхода Польши к морю как для ее собственного развития, так и для советско-польских связей), Силезию, Краков и родной Тарнов. Собеседник Радека писал тридцать лет спустя:

У меня было неотразимое впечатление, что поездка по Польше и, быть может, в особенности атмосфера старых краковских стен оказали на Радека свое влияние: это был как будто не тот человек, что в Москве; казалось, все, что было в нем польского, вышло из него наружу. И думаю, что он тогда искренне и с доброй волей думал о возможности détente и сближения в наших отношениях ${ }^{87}$.

Гуляя в парках Виланова и Лазенок Медзиньский и Радек вели долгие беседы, окрашенные историческими реминисценциями. В Кремле, говорил посланец Сталина, признают убедительными мотивы, по которым Польша не может быть заинтересована предпринять совместную с Германией акцию против Советской Россией. Но Польша может оказаться в таком положении, когда немцы поставят ее перед выбором: либо совместный поход на восток и участие в будущих прибылях либо она сама окажется первой жертвой «Drang nach Osten». Существует и другая возможность: не требуя прямого участия в войне с СССР немцы заставят Польшу уступить им часть Коридора, чтобы создать в Восточной Пруссии плацдарм для нападения на Советы через Прибалтику. «Мы, в Москве, - говорил Радек, размышляли над этим и вправду не были уверены, как бы мы поступили на вашем месте». «Не знаю и я, — со злостью отвечал Медзиньский, — как бы поступили вы. Но я знаю без тени сомнения, как поступим мы». Разве Радек сам не понимает, что польские honor и racja не позволит наследникам Мицкевича, младшим современникам Сенкевича и Жеромского дать в обоих случаях иной ответ, чем «безоговорочное нет»? Однако, вопрос Радека был продиктован Сталиным и ответ на него должен был быть контрассигнован Пилсудским. Двумя днями позже такое подтверждение Радек получил.

События 1935-1939 гг. показали, что опасения Москвы были основательны, а ответ, который дала на них Варшава - правдив. Однако из Кремля, с которым Радек поддерживал шифрованную радиосвязь из советской миссии, заявление Пилсудского выглядело иррациональным, если оно не сопровождается расчетом на помощь Москвы в случае вооруженного конфликта между Польшей и Германией. Следует подумать,

86. Bogusław Miedziński, «Popioły sa jeszcze gorące. Polska polityka zagraniczna w okresie przedwojennym», Wiadomości (Łondyn), 26.10.1952.

87. Bogusław Miedziński, Pakty Wilanowskie, s. 115. Анализ свидетельств Медзиньского и другие польские материалы о визите Радека см.: Arkadiusz Adamczyk, op. cit., s. 196199. 
предложил Радек ошеломленному Медзиньскому, о «чем-то большем, чем разрядка и сближение» между СССР и Польшей. Поскольку привлечение Красной Армии к защите западной границе Польши было бы для вас совершенно неприемлемо, объяснил он, советская сторона готова была бы оказать помощь военными материалами, оборудованием, топливом или сосредоточить свои силы вблизи Восточной Пруссии. Наконец, посланец Сталина передал предложение начать обсуждение этих вопросов представителями генеральных штабов Польши и СССР. К изумлению пилсудчиков ответ их старого Коменданта был вполне доброжелательным: предложение СССР будет рассмотрено, но «в данный момент оно несколько преждевременно». После многих лет враждебных отношений общественность должна вначале освоиться с развитием добрососедских отношений между двумя странами 88 . Было условлено, что Радек и Медзинский будут и впредь поддерживать между собой личный контакт и если на официальных путях возникнут затруднения, то они будут разрешаться путем переписки и встреч между ними.

В Москву Радек «revient enchanté des tendances rencontrées et de l'intelligence des hommes politiques qu'il a approchés» ${ }^{89}$ и немедленно подготовил специальный доклад, в котором с большой убежденностью представил ответ на главный для советских верхов вопрос относительно перемен в политике Польши: «Маневры или поворот?». - «В польской внешней политике происходит поворот» в пользу искреннего сотрудничества с СССР, заявлял Радек, приводя аргументы экономического, внутриполитического, стратегического свойства и высказывания влиятельных пилсудчиков. Решительное изменение внешнеполитических установок Варшавы в отношении СССР, заключал он свой доклад высшему руководству страны, возможно лишь в двух случаях:

Если в Польше начнется революционный кризис, то животный страх за свои головы может толкнуть Польшу против нас. К таким же последствиям могло бы привести решительное поражение Польши в войне с Германией. Вне этих двух возможностей налицо реальная возможность дальнейшего нашего сближения с Польшей, хотя процесс этого сближения может носить затяжной и противоречивый характер 90 .

29 июля Радек был призван в Кремль, где его ждали Сталин, Молотов и Ворошилов $^{91}$. После более чем часовой беседы заведующий БМИ покинул кабинет Генерального секретаря, и в него вошел исполняющий обязанности Наркома иностранных дел Крестинский. Советская дипломатия получила новую установку, которую Крестинский выразил с несвойственным ни НКИД, ни, тем более, ему лично оптимизмом и мотивировкой:

88. Bogusław Miedziński, op. cit., s. 119-120.

89. P. Alphand à J. Paul-Boncour, Moscou, 2.8.1933, DDF, 1-re sér. t. IV : 16 juillet -12 nov. 1933, Paris, 1968, p. 134.

90. Доклад Бюро международной информации № 70 (по Польше № 4) «Польскосоветское сближение», 26.7.1933, АВП, /010/7/24/12/71-81.

91. Посетители, с. 186 
нам нужно форсировать сближение с Польшей, чтобы заставить ее занять определенную позицию и оборвать направленные против нас переговоры с Германией. ...Нам легче, чем Германии договориться с Польше. Поэтому наши шаги в этом направлении, по всей вероятности, скоро увенчаются успехом $^{92}$.

Одновременно руководство НКИД приняло к исполнению указание о снятии с должности Заведующего I Западным (Польско-Прибалтийским) отделом НКИД Николая Райвида, что явилось первым кадровым решением из тех, о которых - для улучшения атмосферы двусторонних отношений просили поляки и которые обещал им Радек ${ }^{93}$. В середине августа Радек вновь посетил Сталина, очевидно, для того, чтобы познакомить его с новым важным посланием от польских «вождей» 94 . Реконструкция этого эпизода на основе имеющихся документов позволяет полагать, что Радек на этот раз выступил вестником решения польских властей о предоставлении льгот для советских экспортеров 95 . Если это предположение верно, заведующий БМИ смог обрести новую ипостась внешнеторгового посредника. Наконец, августовскими публикациями нескольких обширных установочных статей в Известиях и Большевике Радек укрепил свой статус dirigeant советского «общественного мнения» 96 .

Бюро международной информации и его Заведующий достигли вершины своего политического успеха и влияния, путь с которой вел только вниз. Движение по нему было во многом предопределено политическими и организационными концепциями, положенными в основу деятельности Бюро со времени его создания.

\section{Поражение Радека и упадок влияния БМИ (осень 1933 - весна 1934 г.)}

Аргументация, положенная в основу «форсированного сближения с Польшей», основывалась на отмеченном выше финалистском политическом мышления, по-военному спрямлявшем историческую логику назревавшей европейской войны. Она предполагала четкий образ того, как должна вести себя Польша. Ее действия в отношении к Германии и

92. Письмо Заместителя наркома иностранных дел Н. Н. Крестинского полпреду СССР в Варшаве В. А. Антонову-Овсеенко, 4.8.1933, АВП, /0122/17/164/2/94-93.

93. Raport posła RP w Moskwie J. Łukasiewicza do Ministra Spraw Zagranicznych J. Becka, 3.2.1934, AAN/MSZ, / 6764/151.

94. Посетители, с. 188 .

95. Запись разговора корреспондента ТАСС в Варшаве И. Ковальского с корреспондентом ПАТ в Москве Я. Берсоном, Варшава, [ранее 13.].8.1933, АВП, /0122/17/164/5/60; Jan Cisek. Kalendariusz działalności Józefa Piłsudskiego. Uzupełnienia, N.Y., 1992, s. 329; J. Laroche à J. Paul-Boncour, Varsovie, 22.7.1933, DDF, 1-re sér. t. IV, p. 55; «Таможенное соглашение между СССР и Польской Республикой, 18.9/9.10.1933», ДиМ, т. VI, 1933-1938 г2., М., 1969, с. 93-94.

96. См.: Raport posła RP w Moskwie J. Łukasiewicza do MSZ, Moskwa, 16.8.1933, AAN/MSZ, /6748A/91. 
Украине являлись для Кремля критериями целесообразности для продолжения политики сближения. С другой стороны сама эта политика была оптимистически нацелена на «дисциплинирование» поведения Польши, придание ей нужных для СССР качеств. Более того, поскольку германская проблема в понимании Москвы выглядела прежде всего, как угроза соглашения Польши и Германии, которое автоматически отождествлялось со сделкой о передаче немцам Коридора и Верхней Силезии в обмен завоевание для поляков Советской Украины (и, может быть, Советской Белоруссии), любое ослабление напряженности между Берлином и Варшавой приравнивалось к антисоветскому сговору, любые попытки польских властей сблизиться с национальными украинскими кругами (в том числе, в собственном государстве) определялись не только как реанимирование федералистского проекта 1919-1920 гг., но и как подготовка с союзу с Германией. Заложники «диалектического мировоззрения» и «организующей роли партии», высшие советские руководители, были внутренне неспособны понять и принять автономность социального действия (да и в дипломатическом ведомстве пороки советского мышления лишь отчасти умерялись профессиональной осторожностью, практическим знанием того, сколь извилисты пути международной политики, как много промежуточных и противоречащих один другому этапов проходит политическая эволюция).

Нам неизвестно, каковы были фактические основания, позволявшие ОГПУ и украинскому руководству настойчиво заявлять осенью 1933 г. о продолжающейся на Советской Украине подрывной деятельности Польши 97 . Впрочем, для них могло быть довольно и сочувствия, с которым на ее восточных воеводствах воспринимали трагические вести из-за границы и которое Москва интерпретировала как намерение польского правительства «на всякий случай поддерживать и разжигать антисоветские и даже интервенционистские настроения на Западной Украине» ${ }^{98}$. Заведующий Бюро международной информации напрасно доказывал, что «les Polonais ont déjà trop de difficultés avec leurs Ukrainiens pour accepter l'idée d'en incorporer de nouveaux » и «федералистская» концепция Пилсудского стала достоянием истории ${ }^{99}$. «Факты» (точнее, то, что советское мышление признавало в качестве таковых) «убеждали» Москву в обратном: готовясь к войне с СССР, поляки укрепляют свой украинский тыл и предпринимают политические диверсии по подрыву устойчивости Советской Украины. Можно предположить, что даже если бы Варшава пошла на принятие драконовских мер против антибольшевистских украинских организаций, это не привело к коренному изменению оценок ее политики в советских кругах.

97. Анализ антипольской кампании на Украине см.: Raport Kierownika Konsulatu Generalnego RP J. Karszo-Siedlewskiego do MSZ, Kharkow, 31.13.1933, AAN/MSZ, /6751/27-33.

98. См.: О. Н. Кен, А. И. Рупасов, указ. соч., с. 394.

99. P. Alphand à J. Paul-Boncour, Moscou, 2.8.1933, DDF,1-re sér. t. IV, p. 135; Доклад Бюро международной информации № 70 (по Польше № 4) «Польско-советское сближение», 26.7.1933, АВП, /010/7/24/12/80-81. 
Логика взметнувшейся унификационной кампании на Советской Украине генерировала образ ее внешнего врага — «польского фашизма». В том же направлении действовали и антиверсальские навыки предшествующего периода с характерным для него ощущением собственной международной неполноценности - имперская враждебность к самостоятельной Польше и борьба с нею за влияние в Восточной Европе, опыт партнерства с Германией и зачарованность ее огромным потенциалом.

С другой стороны, политическая ориентация, сформулированная Заведующим БМИ и получившая поддержку высшего руководства, вступила в парадоксальное противоречие с литвиновским курсом на сближение с западными оппонентами Германии, прежде всего Францией. С лета 1933 г. оно проходило под аккомпанемент настойчивых предостережений Даладье и Поль-Бонкура о вероломстве поляков, стремящихся поправить свое трудное положение путем стратегического соглашения с Германией (Украина в обмен на Коридор). До сих пор остаются малообъясненными причины, по которым Париж на протяжении второй половины 1933 г. разжигал у советской стороны недоверие к польской политике. Возможно, они крылись в надежде французского правительства достичь реинтеграции Германии в версальские структуры ценой ограниченной территориальной ревизии, предпосылкой чего являлась международная изоляция непослушной Польши. К такой версии склонялся Радек, указывавший, в частности, что «Франция предпочитает платить Германии не из собственного кармана, а из польского», и «если бы поляки вели переговоры с Германией об уступке Поморья, то нынешнее французское правительство вздохнуло бы с облегчением» 100 . Однако Литвинов и его коллеги, сделавшие ставку на развитие отношений с Францией в направлении военно-политического союза, в значительной степени верили - или делали вид, что верили, — в правдивость фантастических сообщений французских контрагентов. Правдоподобна и иная интерпретация (не исключающая, впрочем, первую): компрометируя Польшу, французское правительство и военные круги желали покрепче привязать к себе союзницу без того, чтобы конкретизировать (как того требовала Варшава) обязательства в случае agression flagrante ${ }^{101}$. Со своей стороны, московские сторонники сближения с Францией были склонны думать, что достигнув взаимопонимания с нею они, как само собой разумеющееся, получат в качестве политического приданого Польшу, связанную с Францией вассальными узами. Как бы там ни было, с осени 1933 г. франко-советское сближение развивалось независимо от интересов сотрудничества СССР с Польшей и вопреки ему, чего опасался и чему безуспешно пытался помешать Заведующий БМИ. Вспоминая, как «высшие офицеры не стесняясь в моем присутствии отпускали ругательства по адресу Франции», он констатировал:

100. АВП, $/ 010 / 7 / 24 / 12 / 79$.

101. В этом духе, ссылаясь на мнение Медзиньского и Матушевского, писал в НКИД и Радеку полпред в Варшаве (Письмо полпреда СССР в Варшаве В. А. АнтоноваОвсеенко Члену Коллегии НКИД Б. С. Стомонякову, 28.7.1933 (1 экз. Радеку), АВП, /010/8/31/77/43). 
Не подлежит сомнению, что они хотят усиления отношений с Францией, но они борются против подчинения польских интересов французским. Мы, понятно, должны использовать их антагонизм, но при этом не делать ничего, что могло бы задеть польское самолюбие. Путь в Варшаву идет не через Париж, а только через Варшаву ${ }^{102}$.

Со временем (вероятно, под влиянием парадоксальной несовместимости профранцузской и пропольской линий в советской внешней политике) позиция руководителя Бюро международной информации приобрела еще большую категоричность.

Радек ставит вопрос прямо. Отношения СССР с Польшей и Францией должны быть строго параллельны, но не более, чем параллельны. Польша для СССР значительно важнее политически, дружественный контакт с Францией должен иметь главной и первоочередной целью финансовое и хозяйственное сотрудничество 103 .

Понятно, что такого рода «параллельность» (при любых возможных оговорках) означала оттеснение Франции на второй план в вопросах европейской безопасности.

Под влиянием противоречивых внутренних и внешних, политических и ментальных импульсов короткая эра советско-польского сближения осенью 1933 г. была пронизана драматическими столкновениями, которые Радек пытался сгладить, то побуждая советские ведомства к скорейшему открытию переговоров о воздушном сообщении между СССР и Польшей, то организуя в своем доме встречу польского посланника со звездой дипломатического сезона - первым американским послом в СССР У. Буллитом, то информируя поляков - прежде, чем об этом узнали представители какой-либо иной страны - о возможности вступления СССР в Лигу Наций $^{104}$. Поддержание прямых доверительных контактов между Кремлем и Бельведером, о чем Заведующий БМИ договорился в Варшаве с Медзиньским и Беком, оказалось невозможным. В начале осени Медзиньский сообщил полпредству о желании побывать в Москве с группой польских журналистов (а «если бы он не сумел, то вместо него поедет Матушевский»). По предложению НКИД, проштампованному Политбюро, было решено организовать экскурсию в СССР журналистов различных (в том числе оппозиционных) направлений, от чего польская сторона отказалась. Отсутствие в те дни Сталина и Радека, проводивших отпуск на юге, способствовало успеху маневра Наркоминдела, направленного на выхола-

102. Доклад Бюро международной информации № 70 (по Польше № 4) «Польскосоветское сближение», 26.7.1933, АВП, /010/7/24/12/75.

103 Raport posła RP w Moskwie J. Łukasiewicza do Ministra Spraw Zagranicznych J. Becka, 4.2.1933, AAN/MSZ, /6764/158.

104. См.: О. Н. Кен, А. И. Рупасов, указ. соч., с. 383-389; «Донесение посланника Польши в Москве Ю. Лукасевича министру иностранных дел Ю. Беку, 15.12.1933», ДиМ, т. VI, с. $144,146$. 
щивание потаенного смысла приезда проправительственных журналистов ${ }^{105}$.

Этот маневр был лишь одним из многих проявлений ревнивого недоброжелательства, переходящего в прямую враждебность, с каким в руководстве и аппарате НКИД наблюдали за активной деятельностью Радека - «тщеславного писаки с претензией на всезнание» (a vain scribbler, with the pretensions to omniscience) ${ }^{106}$. Недовольства советского дипломатического ведомства вызывали не только секретные миссии и аналитические разработки Радека, обеспечивавшие его влияние у Сталина. Воздействие на формирование советской политики Заведующий БМИ оказывал и в качестве официозного журналиста, статьи которого воспринимались как выражение внешнеполитического курса Москвы и который при этом оказывался вне контроля со стороны какого-либо регулярного партийного и государственного института, в том числе НКИД. Неприязненное отношение Наркоминдела к контактам БМИ с поляками не укрылось от внимания польских дипломатов, которые стремились оказать умиротворяющее влияние на закулисную борьбу в Москве. В начале осени 1933 г. в беседе с Литвиновым польский посланник предался воспоминаниям о позитивной роли Радека в минских переговорах 1920 г. и варшавской миссии Раевского тремя годами позже. Официальные переговоры, которые полпред Копп вел осенью 1923 г. с польским МИД вызывали опасения, что Красная Армия двинется через Польшу на помощь германской революции, указывал посланник, но «тов. Раевский разъяснил ситуацию и внес успокоение»107. Аппеляция поляков к опыту начала 20-х гг. была напрасной. Руководители НКИД, по всей вероятности, не имели ничего против Раевского, но самостоятельность и активность Радека вызывала у них сильные эмоции. К концу 1933 г. конфликт между Наркоматом по иностранным делам и Бюро международной информации достиг такой остроты, что Член Коллегии НКИД, частично дезавуируя одну из статей Радека, указывал полпреду в Литве на необходимость «еще большей сдержанности в отношении к этому деятелю»108.

Беззастенчивость, с которой в НКИД отзывались о глашатае советской внешней политики и руководителе органа ЦК ВКП(б), была характерна для обстановки рубежа 1933 - начала 1934 гг. В Москве напряженно следили за смягчением напряженности в отношениях между Польшей и Германией. В ноябре 1933 г. Пилсудский получил предложение Гитлера заключить двустороннее соглашение о неприменении силы в двусторонних отношениях. После полуторамесячного промедления диктатор Польши ответил

105. О. Н. Кен, А. И. Рупасов, указ. соч., с. 391-394.

106. Note by W. Strang (HMG Councellor in Moscow), Moscow, 17.9.1931, Public Record Office, London/FO/371/15625/N6477 (высказывание Заведующего 3-м Западным отделом НКИД Е. Рубинина).

107. Дневник Наркома иностранных дел М. М. Литвинова. Запись беседы с Лукасевичем. 5.9.1933, АВП, /0122/17/164/4/168.

108. О. Н. Кен, А. И. Рупасов, указ. соч., с. 553 (речь, вероятно, шла о статье «Германский империализм и фашизация Прибалтики» (Известия, 17.12.1933)). 
согласием, его подписание ожидалось со дня на день. Правящая Москва чувствовала себя обманутой вдвойне - и поляками, и немцами. За несколько часов до обнародования польско-германской декларации 26 января Генеральный секретарь ЦК ВКП(б) сделал на XVII партийном съезде заявления о «зигзагах» в политике Польши, и об опасной политике тех, кто готовится предпринять военные меры против гитлеровской Германии. Дипломатия и военная разведка, партийные агитаторы и государственная печать выражали подозрения в том, что декларация 26 января является частью широкого соглашения, секретные статьи которого предусматривают территориальную сделку за счет СССР. Одновременный срыв намечавшейся польско-советской декларации в пользу сохранения независимости стран Балтии, казалось, подтверждал традиционные страхи ${ }^{109}$. Не развеял их и февральский визит в Москву министра иностранных дел Польши. Дорога к налаживанию двустороннего и международно-политического сотрудничества СССР с Польшей была блокирована.

Неудача «проекта сближения» вызывалась, во-первых, финалистским характером сценария, который с одобрения Сталина разработало Бюро международной информации, и который столь удачно обратили против Радека его оппоненты. На польские объяснения — « для здравомыслящего человека совершено ясна неосновательность каких бы то ни было расчетов на прочное сотрудничество Польши с Германией. Польше нужно было обеспечить себя от агрессии со стороны Германии хотя бы на год-два» был готов ответ: «?! Зачем? Если драться, не лучше ли не давать времени Германии довооружиться?» 110 . Исходные посылки и прогнозы БМИ были верны, но их неопосредованное приложение к реалиям 1933 г. и преломление в реальной политике СССР требовало от поляков забыть о текущих интересах и независимой политике, целиком положиться на Советский Союз и демонстрировать лояльность его внешнеполитическим целям. Ничем не сковывая собственной свободы выбора, Кремль предлагал полякам отказаться от перемирия с Германией, которое он приравнял к союзу. Развертывая гонения на проявления самостоятельной национальной жизни в западной части СССР, Москва фактически потребовала от польского правительства проведения такой же линии в восточных воеводствах. Пророчества оппонентов Радека оказались самосбывающимися, и оптимизм БМИ 1933 г. предстал столь же безосновательным, как и пессимизм НКИД 1931 г. Изучение обстановки на месте и независимая экспертиза, радековский «большой стиль» были дискредитированы. Банальные наблюдения и осторожные оценки, исходившие со стороны руководителей НКИД (одновременно немало потрудившихся над продвижением практических вопросов

109. Мы вынуждены оставить в стороне немаловажный в данном контексте, но требующий подробного рассмотрения вопрос о роли БМИ в формировании новой советской политики в отношении Прибалтийских государств и связанных с этим польско-советских противоречиях.

110. Запись беседы полпреда СССР в Италии В. П. Потемкина с послом Польши П. Высоцким, Рим, 29.11.1933 (с маргиналиями Б. С. Стомонякова), АВП, $/ 0122 / / 17 / 167 / 26 / 4$ 
двусторонних отношений между СССР и Польшей) и других регулярных органов, казалось, подтверждались - до 1 сентября 1939 г. было еще далеко.

Во-вторых, поражение потерпел метод прямой (и нелегитимной) дипломатии, примененный БМИ (Радеком и Раевским), составными частями которого являлись личные переговоры с уполномоченными Пилсудского, поддержание с ними контакта через неофициальных представителей (в частности, корреспондента Gazeta Polska в Москве), общение с дипломатическими представителями в интересах разрешения отдельных вопросов и информирования о намерениях и опасениях Кремля. В дипломатическом маневрировании Варшава переиграла Москву: в то время, как советская сторона преуменьшала политическое значение переговоров с Польшей, она придала этим переговорам максимально возможный резонанс, инспирируя слухи о желании СССР заключить военно-политический союз с Польшей. Так, уже на следующий день после отъезда Радека Начальник Главного Штаба Польши сообщил французскому военному атташе о предложениях Москвы и ответе Пилсудского. Другим (вероятно, главным) адресатом польской indiscrétion была Германия, и трудно сомневаться в том, что фантастическая для ближайшего будущего перспектива объединения СССР и Польши в противостоянии рейху, подтолкнула Гитлера и Auswärtiges Amt к политическому перемирию с поляками. Опровергать сведения о варшавских переговорах советская сторона, разумеется, не могла, и бессильно наблюдала, как польская дипломатия эксплуатирует их сенсационные аспекты в собственных целях и использует оружие, предоставленное им радековской дипломатией в ущерб внешнеполитическим интересам СССР. Неэффективность этого способа поведения должен был признать и сам Радек, совершивший (возможно, по поручению Сталина, с которым он беседовал в начале декабря) попытку помешать сближению Польши с Германией «нормальными» дипломатическими средствами. В беседе с представителями германской прессы в первые дни начале 1934 г. он пытался уверить Берлин:

Glauben Sie nicht, dass bereits etwas entschieden wäre. [...] Wir werden nicht tun, was uns für längere Zeit festlegen könnte. Nichts wird geschehen, was uns für immer die Wege zu einer Politik mit Deutschland verbauen würde. [...] Sie wissen doch, was Litwinow vorstellt. Über ihm steht ein harter and mit festen Willen ausgerüsteter, vorsichtiger and misstrauischer Mann. Stalin weiss nicht, woran er mit Deutschland ist. Er ist unsicher. Das konnte mich anders sein, - wir konnten den Nazi nich anders als mit Misstrauen begegnen. Wir wissen aber, dass Versailles nicht mehr existiert. Sie müssen uns nicht für so dumm halten, dass wir dem Rad der Weltgeschichte in die Speichen fallen. Wir wissen etwas von den deutschen Rüstungmöglichkeiten.

На наш взгляд, эти заявления выражали не столько заинтересованность в улучшении отношений СССР с Германией (и еще менее - к налаживанию стратегического партнерства с нею), сколько стремление, соблазняя Берлин такой возможностью, сорвать завершение немецко-польских переговоров и тем самым вдохнуть новые силы в сотрудничество Польши и СССР. 
О разочаровании заведующего БМИ в действенности искренних бесед с поляками и готовности прибегнуть к обходным маневрам свидетельствует и его размашистое утверждение немцам, будто «meine Liebe zu Polen ist gewiss nicht grösser als zum nationalsozialistischen Deutschland»111.

Наконец, существенную роль в кризисе советско-польского сближения сыграло соперничество Наркоминдела и БМИ. Как отмечалось выше, внесение конкурентных начал в процесс принятия внешнеполитических решений было одной из основных целей Сталина при создании Бюро весной 1932 г. и, надо думать, такое соперничество поддерживалось им и в дальнейшем. Вряд ли приходили в восторг от вмешательства Радека и другие советские олигархи (если не считать Ворошилова, с которым у него установились теплые личные отношения), однако его главным и естественным противником стал НКИД. Когда нарком Литвинов заявлял германскому послу (пришедшему протестовать против статьи Радека), что «наша Коммунистическая партия не имеет внешнеполитических отделов и наш комиссариат осуществляет внешнюю политику как государства, так и господствующей партии», он вступал в противоречие с действительностью, но несомненно выражал кредо Наркоминдела: Бюро международной информации лишено легитимности и НКИД ничего общего с ним не имеет ${ }^{112}$. «Аппарат нашей партии оказался самым могучим историческим аппаратом созидания социализма», - отстаивая свою позицию утверждал К. Радек единственный полноправный делегат от «ЦК ВКП(б) (аппарат)» на «съезде победителей» ${ }^{113}$. Повседневная координация расхоящихся усилий НКИД и БМИ была явно не по силам ни комиссиям Политбюро, ни лично Сталину (В аналогичной ситуации мог оказаться и Пилсудский, однако он поступил иначе. При множественности используемых им внешнеполитических каналов у Пилсудского был один главный докладчик — «kochany Beck», министр иностранных дел, перед которым отчитывались Медзиньский и другие пилсудчики, поддерживавшие контакт с представителями Кремля). Как руководимый Литвиновым Наркоминдел, так и олицетворяемое Радеком БМИ являлись сторонниками советско-польского сближения в интересах противодействия германской экспансии, однако различные представления о методах достижения этих целей внесли свой вклад в первое

111. «Die Botschafter in Moskau R. Nadolny an das Auswärtigen Amt, Moskau, 10.1.1934», Akten zur Deutschen Auswärtigen Politik 1918-1945. Serie C: 1933-1937. Bd. I, 1: 14. Oktober 1933 bis 31. Januar 1934, Göttingen, 1973, с. 325-326. Ср. заявления Радека Бауму и Оберлендеру в августе 1934 г. (G. Hilger, A.-G. Meyer, The incompatible allies: A memoir-history of German-Soviet relations 1918-1945, N.Y., 1953, p. 267-268).

112. Это заявление Литвинов внес в свой служебный дневник, фрагменты которого рассылались его заместителям и в Отделы НКИД (Дневник Наркома иностранных дел Литвинова. Прием Дирксена. 16.5.1933, АВП, /082/16/71/1/203).

113. XVII съезд Всесоюзной коммунистической партии (большевиков). 26 января 10 февраля 1934 г. Стенографический отчет, М., 1934, с. 627, 710. Руководители Отделов ЦК ВКП(б) подлежали избранию от территориальных парторганизаций; заведующий сталинским Секретариатом А. Н. Поскребышев и другие сотрудники ЦК, ставшие делегатами XVII съезда ex officio, располагали лишь правом совещательного голоса. 
поражение политики коллективной безопасности, от которого она так и не смогла оправиться.

Положение, сложившееся в начале 1934 г., с точки зрения польской миссии выглядело следующим образом:

Литвинов к отчетливой неприязнью отнесся к неофициальным беседам. Нынешнее охлаждение атмосферы в наших отношениях наступило формально на участке, представленном Радеком. В то время как Литвинов держался лично безукоризненно (выступления его и Молотова [на ИВ сессии ЦИК СССР в декабре 1933 г. - Авт.]), политическая атмосфера, созданная приездом Радека и его заявлениями, была реализована только там, где мы сами проявляли инициативу — и то, ни одно конкретное дело не получило завершения (авиационная конвенция, хозяйственные отношения), произошли только две персональные замены, обещанные Радеком [...]; в украинских делах Радек, несмотря на мою беседу с ним, ничего особенно важного не сделал.

Тем не менее, полагал Лукасевич, возобновление непосредственного контакта между Радеком и Медзиньским в будущем необходимо уже потому, что в польско-советских отношениях существуют темы, которые нельзя поднимать в рамках дипломатических сношений - поведение печати, украинские и белорусские дела и другие вопросы.

[...] Мои критические замечания в отношении Радека, - завершал посланник свой рапорт в Варшаву, - вытекают лишь из тактических соображений и не имеют ничего общего с действительной оценкой его деятельности. Я считаю его серьезным, искренним и ценным сторонником польско-советского взаимопонимания и убежден, что в настоящий момент, когда доверие покачнулось, он выполняет роль, с нашей точки зрения, позитивную ${ }^{114}$.

Однако влияние Радека и руководимого им Бюро на определение советского внешнеполитического курса было уже подорвано. В конце марта 1934 г. Сталин вновь принял Радека и долго беседовал с ним, но эта встреча, проходившая в присутствии Молотова, Ворошилова, Крестинского и Розенгольца ${ }^{115}$, по своим результатам, надо полагать, была прямо противоположной итогам их бесед наедине весной 1932 г., которые заложили основания нового органа. В середине мая 1934 г. членам Политбюро было разослано предложение относительно «информационного бюро» (автор постановления на этот раз не назывался, а наиме нование органа давалось не с прописной, а со строчной буквы). Новый документ отменял хартию 1932 г. и вводил деятельность БМИ в рутинные бюрократические рамки. Из четырех прежних задач за ним сохранялась лишь одна, соответствующая его названию - «подготовка информаций (сводки, отчеты, выдержки из прессы) по международным делам для ЦК ВКП(б)». Ни о какой проверке сведений или самостоятельном их получении, разработке сотрудниками

114. Raport posła RP w Moskwie J. Łukasiewicza do Ministra Spraw Zagranicznych J. Becka, 3.2.1933, AAN/MSZ, / 6764/148,151-154.

115. «Посетители», Исторический архив, № 3, 1995, с. 125. 
Бюро «новых, крупных вопросов», использовании его материалов для ориентации советской прессы речи уже не было. За ним сохранилось право использовать лишь иностранную печать и «другие иностранные источники» (т.е. впечатления от общения с иностранными дипломатическими представителями), а также печатные материалы «соответствующих советских» (а «не всех», как в 1932-1933 гг.) учреждений. Тем самым Бюро лишалось право доступа к дипломатической переписке, возможность заказывать аналитические разработки в Штабе Красной Армии и ОГПУ, давать задания советским корреспондентам за рубежом и т.д. Постоянный аппарат БМИ (по всей вероятности, в 1933 г. несколько разросшийся за счет привлечения в него квалифицированных авторов) был определен в том же составе, что и в постановлении Политбюро 1932 г. (руководитель, два помощника, технические сотрудники). Если прежде в скудости собственных кадровых ресурсов таилась сила Бюро международной информации (ибо эта скудость служила основанием для привлечения к работе сотрудников любого государственного органа или учреждения), то теперь она лишь подтверждала жалкую роль реформированной структуры. Самостоятельность БМИ (подчиненность лично Сталину) была утрачена и оно отдавалось под надзор Секретариата ЦК ${ }^{116}$. Своеобразным эпилогом короткой истории взлета и падения влияния Бюро в 1932-1934 гг. стало утверждение Секретарями ЦК ВКП(б) «Правил обращения с секретными докладами и сообщениями БМИ», которые окончательно определяли включение радековского органа в общую институциональную структуру, рутинизацию деятельности, обезличивание адресатов информационных сводок и докладов Бюро ${ }^{117}$.

Заведующий БМИ, само собой разумелось, утратил функции специального эмиссара Кремля. Весной 1934 г. эстонские правительственные круги напрасно изъявляли желание установить прямой контакт с Радеком (и руководитель МИД приглашал его в Таллин) $)^{118}$, тщетно осенью 1934 г. Богуслав Медзиньский предлагал нанести визит в Москву или принять Радека в Варшаве, чтобы возобновить дискуссии со своим партнером новый советский полпред откровенно высмеял этот замысел ${ }^{119}$.

Сохранение Бюро международной информации как особого органа можно, по-видимому, объяснить двумя главными обстоятельствами. Во-

116. Об этом свидетельствовал не только особый пункт о порядке назначения сотрудников Бюро, но и посылка «совершенно секретного» постановления новому Секретарю ЦК Жданову. Текст постановления см.: Протокол заседания Политбюро ЦК ВКП(б) № 7 (особый) от 26.5.1934, РГАСПИ/17/162/16/61-62 (опубликовано: О. Н. Кен, А. И. Рупасов, указ. соч., с. 574). Е. А. Гнедин довольно точно определил применительно к 1934 г. статус Бюро: «какая-то группа (или маленький сектор) при секретариате Сталина» (Е. Гнедин, Из истории отношений между СССР $и$ фашистской Германией: Документы и современные комментарии, New York, 1977, c. 13).

117. См.: Протокол Секретариата ЦК ВКП(б) № 11 от 14.7.-20.8.1934, РГАСПИ, $/ 17 / 114 / 567 / 9$

118. О. Н. Кен, А. И. Рупасов, указ. соч., с. 553.

119. Дневник полпреда СССР в Варшаве Я. Х. Давтяна. Беседа с Медзиньским, 9.10.1934, АВП, /0122/18/168/7/64 
первых, высшее партийное руководство отнюдь не утратило потребности в информационно-аналитической структуре, независимой от дипломатического и других государственных ведомств, тем более, что в результате административной реформы Наркоминдела весной 1934 г. он приобрел еще большую внутреннюю монолитность ${ }^{120}$. Одновременно Политбюро проявило недовольство организацией информационной работы Разведывательного Управления Штаба РККА и приняло меры к ее серьезной перестройке ${ }^{121}$. Соответственно за БМИ сохранилось право делать оплачиваемые «заказы (статей, материалов)» и оплачивать какие-то «поручения за границей», и при необходимости альтернативной аналитической деятельности Радека и его сотрудников мог был быть вновь придан больший размах. Во-вторых, роспуск Бюро означал бы прямую дискредитацию Сталина, чья личная инициатива в деле его создания была документально удостоверена протоколами Политбюро и чье покровительство Радеку было едва ли не общеизвестным. По всей вероятности, ограничение полномочий Бюро, «банализация» его статуса и места в структуре ЦК явились выражением компромисса между желанием партийных олигархов и государственных ведомств ограничить роль этого сталинского орудия и стремлением Генерального секретаря сохранить лицо и отстоять свои претензии на единоличное руководство внешней политикой страны.

Обстоятельства, обусловившие кризис концепции БМИ образца 19321933 гг., могут быть осмыслены и в более широком контексте функционирования личных агентств в системе российской авторитарной власти. Исторически, расширение фактического политического пространства самодержца путем передачи функций регулярных учреждений в ведение личных агентств было сопряжено с пассивной природой этих инструментов авторитаризма $^{122}$. В деятельность Бюро, напротив, был изначально встроен самостоятельный динамический компонент, что раньше или позже должно было привести верховную власть к подавлению активности этого новообразования.

Доверительное сотрудничество Сталина с Радеком переместилось в иную сферу: он был использован для «работы по истории» и разработки концепции постреволюционного авторитаризма ${ }^{123}$. Судя по тетрадям дежурных секретарей Сталина, с весны 1934 г. и до своего ареста в сентябре 1936 г. заведующий БМИ лишь дважды посетил его кремлевский кабинет. Тем не менее Радек продолжал свои попытки оказать существенное влияние на отношения СССР с Западом, не без основания (как то показал август 1939 г.) полагая, что их решающим звеном остается Польша. Наряду с исполнением функции видного международника (в

120. См.: О. Н. Кен, А. И. Рупасов, указ. соч., с. 571-574.

121. Е. Горбунов, «Военная разведка в 1934-1939 годах», Свободная мыссль, № 2, 1998, c. $98-103$.

122. См.: П. Мустонен, указ.соч., глава ІІІ (в особенности с. 276, 282).

123. См.: О. Н. Кен, «“Работа по истории” и стратегия авторитаризма, 1935-1937 гг.», Личность и власть в истории России ХІХ-ХХ вв., СПб., 1997, с. 108-116. 
1935 г. Радек возглавил Иностранный отдел Известий) - неофициального комментатора государственной политики ${ }^{124}$, он, ссылаясь на якобы известное ему истинное мнение Кремля, стремился ослабить советское давление на Польшу. С начала 1934 г. это давление основывалось на утверждении, что Варшава координирует свою внешнюю политику с антисоветскими планами Берлина заключила с ним соглашение о совместном военном переделе Восточной Европы. В приватных беседах с польскими дипломатами Радек неоднократно давал понять, что «не верит в существование тайных польско-германских соглашений» и более того, Сталин, якобы, придерживается сходной оценки ${ }^{125}$.

Еще дальше Радек пошел в разговоре с послом США У. Буллитом, состоявшемся в июне 1935 г. (вскоре после ознакомительной поездки посла в Варшаву). Американский дипломат записал:

Радек начал острить по поводу моей беседы с Беком в Польше. Я спросил его, что он знает о нашей беседе. Он сказал, что готов держать пари, что имеет более полный отчет об этой беседе, чем тот, что я представил своему правительству. Я ответил, что не сомневаюсь в этом, поскольку я счел нашу беседу настолько незначительной, что не представил никакого отчета. Он ответил, что, как бы ни думал я сам, Бек счел нашу беседу достаточно важной, чтобы представить полный доклад об этой беседе польскому правительству. Я сказал, что поскольку говорил все время Бек, у меня нет возражений, что бы он ни докладывал. Радек ответил, что это совершенно верно, что Бек скорее сообщал о том, что он сказал мне, чем то, что я сказал ему.

Я затем спросил Радека, как ему удалось узнать, что Бек сообщил польскому правительству. Радек ответил, что смерть Пилсудского [в мае 1935 г. - Авт.] оказалась весьма полезной для советского правительства по крайней мере в одном отношении, а именно, что пока Пилсудский был жив, Бек должен был докладывать ему одному, но теперь, когда Пилсудский умер, в Польше существует нечто вроде «Политбюро», которому обязаны докладывать все министры, и советское правительство имеет в этом «Политбюро» представителя, который в точности сообщает советскому правительству, что докладывает каждый из польских министров.

Я спросил его, о чем докладывал Бек. Он ответил, что после похорон Пилсудского Бек докладывал о двух вещах; первое, о беседе между Герингом и Лавалем; второе, о его беседе со мной. Радек сказал, что Бек доложил, что он считает, что ему удалось убедить меня в том, что версия о секретном взаимопонимании между Германией и Польшей лишена малейшего основания и что позиция польского правительства по отношению к Восточному пакту базируется единственно на решимости Польши никогда не согласиться позволить, чтобы нога российского или немецкого солдата ступила на польскую землю, и она никогда не разрешит самолетам Германии или России использовать Польшу в качестве коридора.

124. «В одной из последних бесед с Берсоном Радек сказал, что дружественные отношения могут существовать только на основе постоянного сотрудничества, и это - искреннее, по моему мнению, определение принципиальной позиции СССР по отношению к нам» (List J. Łukasiewicza do T. Schaetzla, Moskwa, 16.10.1934, AAN/MSZ, /6753/126-127).

125. Raport chargé d'affaires RP w Moskwie H. Sokolnickiego do MSZ, Moskwa, 15.1.1935, AAN/MSZ, /6753/159. 
Это именно то, что Бек действительно говорил мне, и точность информации Радека, как представляется, указывает на то, что его заявление относительно присутствия советского агента в высших органах польского государства является достоверной. [...] Возможно, конечно, что Радек неверно указал на источник его сведений, но он изъяснялся с такой свободой и доверительной дружественностью и его информация была настолько точна, что я склонен верить в то, что он говорит совершенную правду. Радек сказал, что заявление Бека польскому Совету о его беседе со мной устранило последние остатки подозрений у советского правительства относительно существования секретного польско-германского соглашения ${ }^{126}$.

Мы вряд ли получим достоверные сведения из архивов Кремля и Лубянки относительно источника информированности Радека, тем более никогда удастся понять всю совокупность мотивов, заставлявших его рисковать своей головой. Желал ли он предостеречь - через «неконвенциального» Буллита - польские власти? Или заверить их в том, что проводимая Польшей «политика балансов» адекватно воспринимается в Москве и тем самым побудить Варшаву к продолжению независимой политики? Не вызывает однако, сомнений, что лишенный своих прежних полномочий Радек остался верен взглядам на необходимость равноправного политического партнерства между Польшей и Советской Россией, которые в 1933 г. пытался привить советской внешней политике ${ }^{127}$. Ясно и то, что пути Карла Радека в середине 30-х гг. окончательно разошлись с этой политикой.

\section{Э пилог}

С 1934 г. процесс концентрации в руках Сталина фактических полномочий в деле формирования и проведения международной политики СССР, выразившийся ранее в оттеснении комиссиями Политбюро самого этого органа и во вторжении БМИ в сферу деятельности регулярных государственных институтов, приобрел новые формы.

Их существо состояло в использовании Кремлем официальных представителей СССР - сотрудников Наркомата иностранных дел и Наркомата внешней торговли - для выполнения политических и информационных задач, которые ставили перед ними руководители Политбюро и которые выходили далеко за рамки их служебных функций. В результате институциональной базой секретной дипломатии становились государственные ведомства, руководители и сотрудники которых были в той или иной степени осведомлены о специальных поручениях представителей Кремля. Эти инновации прослеживаются в «особой миссии» Давида Канделаки (1935-1937 гг.). Неискушенный в международной дипломатии (до 1930 г. он

126. W. C. Bullitt to Secretary of State, Moscow, June 21, 1935 ( «Strictly confidential for the Secretary and Undersecretary»), National Archives, Washington DC/SD/760C.61/692.

127. «Мы всегда утверждали, что 35-ти миллионный, энергичный, дерзновенный это ценность. Пусть и бедный, как мы, но хорошо было бы придти к соглашению», повторил Радек в своей едва ли не последней беседе с представителем польского правительства (Notatka attaché wojskowego RP w Moskwie K. Zaborowskiego «Rozmowa z Radkiem dnia 14.3.1936 r.», CAW, /1775/89/1136/235-236). 
работал в Наркомате просвещения Закавказской Федерации), Канделаки в 1934 г. был направлен на важнейший заграничный пост Наркомата внешней торговли - торгового представителя в Берлине. Его коллегам в полпредстве было прекрасно известно, что Канделаки имеет «доверительные инструкции лично от Сталина и вправе не ограничиваться чисто экономическими вопросами при переговорах с немцами». В помощь Канделаки был придан советник полпредства Сергей Бессонов, который иногда направлял доклады лично Молотову ${ }^{128}$. Смысл зондажных бесед, которые эти дипломаты вели в неофициальном качестве с ведущими представителями правительственных и деловых кругов, был (по меньшей мере, в общих чертах) известен руководителям Наркоминдела, и Заведующий его 2-ым Западным отделом даже дружески указывал Бессонову на необходимость тщательнее скрывать свою фактическую подчиненность торпреду Канделаки $^{129}$. При этом полпред в Берлине Яков Суриц выполнял не менее ответственные задания по изучению тенденций германской политики и по верификации сведений и рекомендаций, которые посылал в Кремль Канделаки ${ }^{130}$. Тем самым дипломатическое ведомство до известной степени контролировало поведение сталинского эмиссара.

Ставшие известными документы рисуют картину не двух параллельных центров дипломатической игры, двух политических линий и двух противоположных методов ее реализации, а проведения средствами неофициальной и официальной дипломатии, некоей согласованной политики, в рамках которой в Москве - как, впрочем, и в Париже, Лондоне или Праге, - продолжался спор между сторонниками умиротворения Германии и их оппонентами. В тайной дипломатии Кремля дерзкий налет уступил место постоянному патрулированию чужих вод; пиратствующего по его приказу «специального корреспондента» заменил корсар с государственной лицензией. Утверждения С. Гинзбурга (В. Кривицкого) о том, что в 1933-1934 гг. Радек «ежедневно консультировался со Сталиным, встречаясь с ним иногда по нескольку раз на дню» и «каждая написанная им фраза тщательно изучалась Сталиным» ${ }^{131}$, безусловно, грешат преувеличением, но вместе с тем отражают верное ощущение тогдашних аппаратчиков, что деятельность Заведующего БМИ направлялась лично Сталиным, была выражением его особой политической воли. С декабря 1934 г. по май 1937 г. Канделаки побывал в кремлевском кабинете Генерального секретаря 16 раз, и всегда тот принимал его вместе с членами Политбюро (обычно - Молотовым, Кагановичем, Ворошиловым, а иногда и с Калининым) и, зачастую, с наркомами внешней торговли и иностранных дел, другими высокопоставленными функционерами. Судя по секретарским записям, Давид

128. Е. Гнедин, указ. соч., с. 35.

129. Личное письмо Заведующего 2-м Западным отделом НКИД Д. Г. Штерна советнику полпредства СССР в Берлине С. А. Бессонову, 17.3.1935 (N 14627), АВП, $/ 082 / 18 / 80 / 3 / 33$

130. См.: «Записка М. М. Литвинова И. В. Сталину, 3.12.1935», Известия ЦК КПСС, № 2, 1990, с. 211.

131. В. Кривицкий, Я был агентом Сталина, М., 1997, с. 21. 
Канделаки провел наедине с Сталиным лишь 40 минут - на следующий день после опубликования 2 апреля 1937 г. правительственного постановления о его переводе из Берлина в Москву132. Когда на рубеже 19361937 гг. зондажные беседы Канделаки достигли своей кульминации, письменные директивы для него были составлены Литвиновым, подправлены Сталиным и скреплены подписями четырех ведущих членов Политбюро ${ }^{133}$.

Перенос центра неофициальной деятельности в регулярные институты выразился также в частичном возвращении Наркоминделу функций контроля за печатью. С конца 1933 г. Отдел печати НКИД получил право контролировать («просматривать и визировать») радиопередачи московского радио на иностранных языках ${ }^{134}$. Заведующий Иностранным отделом Известий С. Раевский, который сыграл крупную роль в становлении БМИ, в начале 1935 г. перешел на работу в дипломатическое ведомство, возглавив издаваемый НКИД Le Journal de Moscou135; близкий к нему журналист Е. Гнедин, прежде сотрудничавший с радековским Бюро, получил официальное назначение в берлинское полпредство (в его обязанности попрежнему входила информационно-аналитическая работа - заведование Отделом печати полпредства) ${ }^{136}$. В продолжение той же тенденции в июне 1935 г. решением Политбюро был прекращен выпуск Бюллетеня иностранной печати БМЙ ${ }^{137}$. Даже скромная вневедомственная международно-политическая экспертиза теряла право на существование. Вскоре после сентября 1936 г. Бюро международной информации при ЦК ВКП(б) прекратило свое существование.

Наступила эпоха большого террора, в муках которого были окончательно стерты столь важные для начала 30-х гг. разграничительные линии между высшей партийной властью и авторитетом государственного ведомства, авторитарными притязаниями Сталина и коллективной ответственностью Политбюро, личной дипломатией и государственной политикой. Представленный выше очерк институциональных и кадровых (и одновременно - внешнеполитических) решений показывает сложные пути постепенного приближения к этому итогу. В области международной дипломатии, как и во внутренней политике, Сталин-самодержец оказался вынужден уступить сплоченной партийно-государственной иерархии, Сталин-вождь партии и народа взял над нею верх. Авторитарная воля и регулярные институты превратились в атрибуты сталинской тотальности,

132. «Посетители», Исторический архив, № 4, 1995, с. 50.

133. Н. А. Абрамов, Л. А. Безыменский, «Особая миссия Давида Канделаки», Вопросы истории, № 4-5, 1991, с. 149-151.

134. Протокол заседания Политбюро ЦК ВКП(б) № 147 (особый) от 15.10.1933, РГАСПИ, /17/162/15/98.

135. Протокол заседания Политбюро ЦК ВКП(б) № 23 от 3.4.1935, там же, /17/3/962/13

136. Протокол заседания Политбюро ЦК ВКП(б) № 19 от 3.1.1935, там же, /17/3/957/10.

137. Протокол заседания Политбюро ЦК ВКП(б) № 27 от 21.6.1935, там же, /17/3/965/47. 
самоотождествились и растворились в тоталитарном комплексе советской политики.

Арестованный тремя годами ранее, Карл Радек погиб в 1939 г. ${ }^{138}$. Давид Канделаки состоял на службе до 1938 г. и был казнен в том же году. Как говаривал самый понятливый из приближенных Сталина - долгожитель Каганович: «Вот, брат, великая диалектика в политике, какою обладает наш великий друг и родитель в совершенстве» ${ }^{139}$.

The European University at St. Petersburg

191187 St. Petersburg

3, Gagarinskaya str.

ken@eu.spb.ru

138. О. Г. Шатуновская называет другую, кажущуюся невероятной дату: 1946 (Jana Kutin, Andrej Broido, eds., Ola Shatunovsky. Memoirs. http://math.ucsd.edu/ broido. 1996. Рассказ 25).

139. «Письмо Л. М. Кагановича Г. К. Орджоникидзе, 12.10.1936», О.В.Хлевнюк и др., сост., Сталинское Политбюро в 30-е годы, М., 1995, с. 151. 